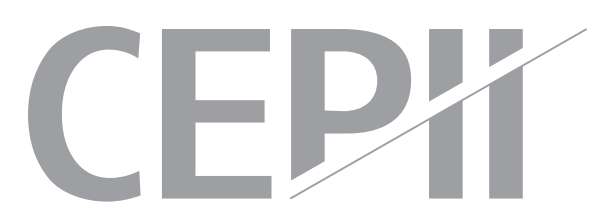

\title{
Let's Try Next Door: Technical Barriers to Trade and Multi-destination Firms
}

Auteur Lionel Fontagné \& Gianluca Orefice

\section{Highlights}

- Stringent TBTs drive the average firm out of the market with a magnified effect for multi-destination players, who are encouraged to redirect their exports to other destinations (free of TBT concerns).

- Multi-destination firms are more likely to exit as a response to a stringent TBT. Thus, the imposition of a stringent TBT, by pushing multi-destination (high-productive) firms out of the market, reduces the average productivity of incumbent firms (i.e. the welfare of the imposing country).

- We combine aggregate estimations at sector-destination level with firm-level estimations and find that stringent TBTs represent mainly increases in fixed (more than variable) trade costs, with trade elasticity magnified for more homogeneous sectors. 


\section{Abstract}

Stringent Technical Barriers to Trade (TBT) are expected to drive exporters out of the markets imposing these hurdles. However their impact will vary, with some exporters being able to refocus on TBT-free markets. By matching a database of TBT measures raised as concerns at the WTO (Specific Trade Concerns -- STCs), with a firm-level panel of French exporters, we show the complex effects of restrictive TBT measures on the different margins of trade. We show that the negative effect of TBT on export participation is magnified for multi-destination firms, which can divert their exports towards TBT-free destinations. Moreover, we conduct aggregate level estimations to show that the effect of stringent TBTs in reducing export flows is magnified in more homogeneous sectors. Observing the shape of the firm distribution at sectoral level and the aggregate elasticity of export to trade cost, we shed light on the fixed component of the additional cost imposed by TBTs on exporters.

\section{Keywords}

Non-tariff Measures, TBT, Multi-destination Firms, Trade Margins.

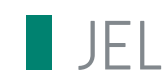

F13; F14.

\section{Working Paper}

\section{CEPI}

CEPII (Centre d'Etudes Prospectives et d'Informations Internationales) is a French institute dedicated to producing independent, policyoriented economic research helpful to understand the international economic environment and challenges in the areas of trade policy, competitiveness, macroeconomics, international finance and growth.
CEPII Working Paper

Contributing to research in international economics

C C CEPII, PARIS, 2016

All rights reserved. Opinions expressed in this publication are those of the author(s) alone.

$\begin{array}{ll}\text { Editorial Director: } & \text { CEPII } \\ \text { Sébastien Jean } & \begin{array}{l}113, \text { rue de Grenelle } \\ 75007 \text { Paris }\end{array} \\ \text { Production: } & +33153685500 \\ \text { Laure Boivin } & \text { www.cepii.fr } \\ \text { No ISSN: } 1293-2574 & \text { Press contact: presse@ }\end{array}$




\title{
Let's Try Next Door: Technical Barriers to Trade and Multi-destination Firms ${ }^{1}$
}

\author{
Lionel Fontagné (PSE - Université Paris 1 \& CEPII)*
}

Gianluca Orefice (CEPII) ${ }^{\dagger}$

\section{Introduction}

Technical Barriers to Trade (TBTs) in the areas of quality, labeling and technical standards increase the cost of exporting into the country adopting such measures. The imposition of TBTs can raise the variable costs of producing the exported goods: technical standards require upgrading or at least adaptation of products or packaging, and varying standards across destinations reduce opportunities for economies of scale. However, this additional cost may also become a fixed cost (new product design, adaptation of the production chain) thereby, discouraging exporters from serving markets with TBTs.

In a model with heterogeneous firms, the productivity cut-off for exporting differs with accessibility of the destination (for a given exporting country) and less productive firms will exit from more difficult destinations (Chaney, 2008). However, not only small firms exit because they are close to the cut-off point: multi-destination exporters, by having low diversion cost, have the option of diverting trade to other destinations that do not impose TBT measures. Exporters will compare the (fixed and/or variable) costs of satisfying the new standard to the cost of diverting shipments: diversion to a new destination (at the extensive margin) will impose a fixed entry cost, while diversion towards an existing destination (at the intensive margin) will impose an incremental cost for reaching marginal consumers (Arkolakis, 2010).

\footnotetext{
${ }^{1}$ This paper has benefited from funding from the European Commission (EC) FP7 within the PRONTO (Productivity, Non-Tariff Measures and Openness) project, grant agreement 613504. The views expressed here do not reflect those of the EC. We are grateful to Maria Bas, Giorgio Barba Navaretti, Matthieu Crozet, Ron Davies, Anne-Célia Disdier, Sebastien Jean and Camilo Umana-Dajud and participants in the PRONTO conference (Vienna), University of Bergamo, CEPII, University of Bari and ISGEP Conference (Pescara).

*106-112 Bd de l'Hôpital, F-75647 Paris Cedex 13 (lionel.fontagne@univ-paris1.fr)

$\dagger 113$ rue de Grenelle - 75007 Paris (gianluca.orefice@cepii.fr)
} 
The higher the cost of complying with the TBT, the higher the probability that exporters will focus on other destinations. Given that diversion of exports comes at a cost, incumbent exporters close to the exporting cut-off will neither be able to comply with the standard nor to divert their exports (given their insufficient productivity). Thus, not all firms will divert their exports when the trade restrictiveness of a TBT is high. Multi-destination firms, by having lower diversion costs, are able to switch destination countries more easily than other firms. The research question addressed in this paper concerns such asymmetric effect of trade-hampering TBTs on the export margins of heterogeneous firms, with a focus on the reorientation of exports of multi-destination exporters. ${ }^{2}$

While the peculiarity of multi-destination firms as more "able" or productive has already been highlighted in the literature (see Bernard et al. (2011) and Wagner (2012)), ${ }^{3}$ we explore here a different characteristic of multi-destination firms: by benefiting from a wide portfolio of alternatives, multi-destination firms are expected to be more able than other firms in diverting trade towards TBT-free destinations (all else being equal). We accordingly control in all our estimations for an (export based) measure of firm's productivity to isolate the effect of being multi-destination from a more general size or productivity effect.

To investigate the research question described above, we need to focus on restrictive TBTs. The Specific Trade Concerns (STCs) raised by affected exporting countries in the World Trade Organization (WTO) TBT committee are a good reflection of these. ${ }^{4}$ Exporting countries will concentrate their claims on the most restrictive TBTs, because there is a cost of complaining: trade representatives have a certain amount of time and energy to allocate among a potentially very large number of idiosyncratic regulations. Thus, a focus on the TBT-market pairs highlighted by the trade representatives in the TBT committee should

\footnotetext{
${ }^{2}$ In a recent paper Héricourt and Nedoncelle (2016) show that destination-diversified firms are more able to handle exchange rate risks (i.e. volatility in the real exchange rate).

${ }^{3}$ Bernard et al. (2011) and Wagner (2012) respectively on US and German data observe that exporters serving a larger number of destinations are more productive. In section 3.2 we use French data to show the same kind of evidence. We show that multi-destination firms, which account for the highest share of exports among French exporters: (i) charge lower export price, (ii) export more and (iii) are more reluctant to exit a market.

${ }^{4}$ According to multilateral rules (TBT agreement Art. 2.5): "A Member preparing, adopting or applying a technical regulation which may have a significant effect on trade of other Members shall, upon the request of another Member, explain the justification for that technical regulation. The TBT committee is the place where such justification shall be provided."
} 
capture the most restrictive trade measures. This comprises the sub-sample of technical measure-destination combinations for which trade diversion should be observed.

We combine this information with firm level custom data for the universe of French exporters in order to uncover the usual adjustments to exports at the extensive and intensive margins. In line with our theoretical motivation, we define an "exporter" as a legal unit (identified by her administrative identifier) exporting within a four digit product category of the harmonized system (HS4). In other words, a legal unit exporting in two different HS4 categories is assumed to have paid twice the fixed cost of launching a new variety (once for each HS4 category). The HS4 level of product aggregation was chosen for its coherence with TBT data. ${ }^{5}$

Our first hypothesis is that firms unable to cope with the additional fixed/variable cost of a restrictive TBT will simply exit the market. Accordingly, we expect a positive effect of stringent TBTs on firms' exit probability - with an induced effect on the market structure and competition in the country imposing the TBT. This effect is expected to be magnified for multi-destination players able to redirect their shipments towards other destination countries with less stringent TBTs. Since we do not have a continuous measure of stringency (a TBT imposed by an importer is challenged or not in the WTO committee), we compare destination with TBT concerns to destination with no TBT concern, within the (firm specific) range of destinations contemplated by the individual exporter in a given HS4.

Our second hypothesis is that multi-destination firms will look for new destinations and expand their geographical scope as a result of stringent TBTs, and will bear the cost of entering new markets with less stringent TBTs. Again, we simply compare destinations with and without TBT concerns. We test these assumptions using our data.

By observing the shape of the firm distribution at the sectoral level, and the aggregate elasticity of exports to trade costs, we can also assess how the two trade margins react to a change in trade costs - in our case, imposition of a stringent TBT. This helps in clarifying the nature (fixed or variable) of the cost associated with a TBT. To our knowledge, this is $\overline{5}$ TBT concerns are also recorded at the HS4 level. 
the first study to estimate this effect and to characterize the nature of the cost imposed on exporters, based on structural estimation of the components of the observed elasticity.

Our findings support our reasoning. We show that the mean effect of the presence of a stringent TBT within an HS4 product category for a given destination is to induce exit of exporters. This effect is stronger for exporters with a portfolio of markets that includes many destinations that are free of TBTs for the considered HS4 category. This diversion effect is robust to controlling for firm size (multi-destination firms are also bigger than other firms). A side effect of this selection is to increase the market share of incumbents: we find that some multi-destination firms that choose to remain in the market and comply with the TBT, enjoy lower competition in that destination and increase exports. We also find support for our prediction regarding the search for new - TBT free - destinations: the presence of a stringent TBT within an HS4 product category for a given destination incites exporters to bear the fixed cost of entering new markets. This effect is magnified for exporters with an initially larger set of destination countries without TBTs, suggesting the presence of economies of scope in market access - an element not present in our theoretical benchmark. Overall, the imposition of a stringent TBT pushes multi-destination firms out of the market and affects the welfare of the imposing country by reducing the average productivity of incumbent firms: the anti-competitive effect of TBTs is aggravated by the exit of multi-destination firms who have (on average) high productivity levels. Finally, we provide evidence based on aggregate level estimations which support the theoretical predictions in Chaney (2008): stringent TBTs reduce export flows at the sector-destination level to a larger extent for more homogeneous sectors (i.e. sectors where smaller and less productive firms account for more export sales). The strong negative effect of TBTs on aggregate export flows combined with the null effect on the intensive margin of the average firms, suggest that stringent TBTs mostly result in increases in fixed (rather than variable) trade costs, see Chaney (2008).

The rest of the paper is organized as follows. Section 2 summarizes the existing literature on the trade effect of TBTs. Section 3 describes the data and presents some stylized facts. Section 4 discusses our empirical strategy. Section 5 presents the results. Section 6 reports 
aggregate level estimation results and section 7 concludes.

\section{Literature Review}

TBTs are covered by a WTO agreement which (in a nutshell) means that technical regulations, standards, and conformity assessment procedures must be implemented in a transparent and non-discriminatory way. ${ }^{6}$ Member countries are encouraged but not obliged to base their measures on international standards. TBTs are subject to triennial review by the WTO. The most recent review led to the publication of a report in December 2015, and highlighted the rapid increase in the notification of TBT measures (table 1 ). Since the first review in 1997 the number of notifications of TBTs has risen by $254 \%$. This is however a conservative statistic since it assumes that all member countries provide such notifications.

Since not all countries follow the WTO recommendation of compliance with international standards, for given categories of products there is a variety of standards of different restrictiveness in place across destinations. This implies that businesses have to duplicate the cost of compliance across destinations. However, efforts to alleviate the impact of TBTs are generally made at the regional level, or within the framework of deep integration agreements. ${ }^{7}$ The impact of these attempts on the exports of members and third parties has been examined by several authors in the literature. Baller (2007) use bilateral trade data at the 3-digit level of the Standard International Trade Classification and examines the trade impact of harmonization (i.e. adoption of a common standard which might be more stringent than the original standard) and mutual recognition (allowing exporters to comply with the least stringent standard in the region) agreements on testing procedures. A two-stage gravity estimation provides nuanced results. Mutual recognition rather than harmonization, is shown to have a strong and positive effect on agents. Third countries do not benefit from harmonization. Chen and Mattoo (2008) adopt a different perspective and analyze the implications for third countries of regional initiatives which deal with technical barriers. The two options - of

\footnotetext{
${ }^{6}$ According to the WTO: "Members shall ensure that technical regulations are not prepared, adopted or applied with a view to or with the effect of creating unnecessary obstacles to international trade".

${ }^{7}$ See WTO (2011) and Orefice and Rocha (2014) for detailed evidence on Preferential Trade Agreements containing provisions on TBTs.
} 
harmonization and mutual recognition - should have different impacts on trade, especially for third country exporters, and in particular when regional standards are associated with strict rules of origin. Harmonization is shown to impact positively on both the likelihood and the volume of trade within the region. Although the impact of harmonization on a third country's exports is positively correlated with the country's ability to meet the standards, third countries' exports suffer overall. Mutual recognition has similar positive impacts on intra-regional trade but the effect on third countries exports to the region is ambiguous since tight rules of origin negate the benefits of mutual recognition for third country exporters. However, these conclusions are centered very much on harmonization / mutual recognition among developed countries. Disdier et al. (2015) analyze how harmonization of technical barriers between developed and developing countries affects international trade. Using a gravity equation, they show that as a result of the deep integration associated with standards provisions included in such economic integration agreements, developing country partners' trade with the North expands but at the expense of their trade with non-bloc developing partners. Moreover, harmonization on the basis of regional standards has a negative impact on the exports of developing countries to developed markets. Essaji (2008) uses US import data at the HS8 level for agricultural, mining, and manufacturing imports to examine the impact of technical regulations. The potential endogeneity of technical regulations is addressed using instrumental variables. The results confirm that technical regulations substantially hinder developing countries' exports.

While there is ample evidence on the negative or positive effects of TBTs on trade (depending on the measure used), on their enforcement and the market failures potentially corrected by these measures, ${ }^{8}$ little is known about how the different margins of trade are affected by TBTs, i.e. how technical measures shape the distribution of exporters to the imposing markets. An exception is Bao and Qiu (2012) which studies the effects of TBT on trade, based on TBT notifications in the period of 1995 - 2008. Using a two-stage gravity model, the authors find that TBTs reduce the extensive margin of exports but increase the intensive

\footnotetext{
${ }^{8}$ See Disdier et al. (2008) for an illustration of Sanitary and Phytosanitary (SPS) measures and TBTs. Li and Beghin (2012) perform a meta-analysis of 27 published articles on the trade impact of SPS and TBT measures.
} 
margin. However, this result is based on aggregate data and we know little about how individual exporters with different levels of productivity adjust to stringent TBTs. Data availability is the main obstacle to uncovering these complex mechanisms.

\section{Data and stylized facts}

Our analysis overcomes the data limitations that apply to previous studies. We exploit two important databases: a recently-constructed database on STCs and a database of French firm exports.

\subsection{The STCs database and examples of TBT measures}

TBT measures cover technical regulations, standards and procedures not included in the scope of Sanitary and Phytosanitary measures (which relate to human/animal and plant protection). According to the WTO a technical regulation falling under the TBT agreement is "a document that lays down product characteristics or their related processes and production methods, including the applicable administrative provisions, with which compliance is mandatory"; a standard is "a document approved by a recognized body, that provides, for common and repeated use, rules, guidelines or characteristics for products or related processes and production methods, with which compliance is not mandatory"; a conformity assessment procedure is "any procedure used, directly or indirectly, to determine that relevant requirements in technical regulations or standards are fulfilled" (see WTO (2014) p.13). ${ }^{9}$ TBTs apply to technical requirements introduced: (i) for health or safety purposes, (ii) to standardize products, (iii) to ensure quality standard, or (iv) to avoid consumer deception.

The recently-released WTO database on STCs records concerns raised in dedicated WTO committees. ${ }^{10}$ Here we focus on concerns raised in the TBT committee which provides WTO members with a forum to discuss issues related to TBT measures imposed by other

\footnotetext{
${ }^{9}$ Examples of technical regulation are: "maximum permitted levels of lead in paint used on toys" or "emission requirements for diesel engine" or "cosmetic labeling" (requirement of describing the chemical composition in the label of personal hygiene products).

${ }^{10}$ The dataset is available at http://www.wto.org/english/res_e/publications_e/wtr12_dataset_e. htm
} 
members (STCs). When a country complains about a TBT measure imposed by another WTO member country (the imposing or maintaining country), it must specify the product concerned, the type of concern regarding the measure, and the objective of the measure. This information provides a systematic set of all TBT measures perceived by exporters to be sizable trade barriers (i.e. measures sufficiently important for countries whose exports are affected to raise a "concern" in the WTO TBT committee). Thus, we rely on barriers to trade. This is the main advantage of using the STC dataset rather than other sources. Indeed, other datasets (as TRAINS or Perinorm) list all the TBT measures imposed by a country mixing together TBT measures which restrict trade with measures that might even increase trade. ${ }^{11}$

Overall, we have 318 STCs raised in the WTO TBT committee during the period 19952011. Each STC corresponds to a concern raised by one or more countries in relation to a TBT measure imposed by one or more of their trading partners. This figure is conservative compared to the cumulated number (more than 13,000) of notifications during the period 1995-2009 reported in table 1 . We are observing the most stringent TBTs, which is in line with our research strategy. For each concern, we have information on: (i) the country or countries raising the concern and the country imposing the measure, (ii) the product codes (HS 4-digit) involved, (iii) the year in which the concern was presented to the WTO, and (iv) whether it has been resolved and how. Since we have detailed data on French firm exports in the period 1995-2007, in our econometric exercise we focus on a sub-sample of concerns raised by the EU during 1995-2007. ${ }^{12}$ Moreover, given the lag structure of our econometric exercise (see section 4), in order to be consistent over the entire paper, we rely on the 1997-2007 period.

Based on the full sample of STCs, table 2 presents descriptive evidence for the sample of STCs on TBTs used in our empirical exercise. Table 2 column 2 shows that the number of countries targeted by (at least one) STC is increasing over time. Column 3 shows that the

\footnotetext{
${ }^{11}$ Some TBT measures indeed can boost trade by addressing problems of asymmetric information or network externalities (Fontagné et al., 2005; Moenius, 2004).

${ }^{12}$ Over the period 1995-2007 the EU raised 159 STCs.
} 
number of HS-4 chapters with at least one TBT concern has been increasing exponentially over the period analyzed.

Our dataset also provides information on the primary object of the STC on TBTs. This allows us to characterize the nature of the underlying TBT measure. Table 3 presents five most frequent objectives reported in the list of STCs on TBTs. Table 4 presents the number of HS-4 chapters under STCs by imposing country. ${ }^{13}$ We find that the EU and China have been targeted frequently by STCs on TBTs. This does not mean that EU and China are particularly active in imposing TBTs, rather it is an indication that the EU and China are attractive markets for exporting countries, and thus often targeted by STCs when they impose TBT measures.

An interesting labeling measure example preventing trade was the concern raised by Peru in 2001 against the EU. According to the Peruvian government, EEC regulation 2136/89 prevented Peruvian exporters from continuing to use the trade description "sardines" for their products. Peru submitted that according to the relevant Codex Alimentarius standards (STAN 94-181 rev. 1995), the species "sardinops sagax sagax" is listed as among those species which can be traded as "sardines". Thus, Peru considered that the regulation constituted an unjustified barrier to trade (Articles 2 and 12 of the TBT Agreement and Article XI:1 of GATT 1994). This measure was also solved by mutual recognition. ${ }^{14}$

In the empirics we use only STCs raised by EU. The first example is the concern raised by the UE representative in October 2010 in the WTO TBT committee against China's new General Safety Technical Code for Textile Products. ${ }^{15}$ This measure sets a mandatory limit $\mathrm{PH}$ value for textile products, prohibited the presence of the aromatic Amines 2.4 and 2.6 Xylidine in textiles, and set a maximum level of $20 \mathrm{mg} / \mathrm{kg}$ for acrylamine dyes. According to the complaining country this measure had no impact on consumer's health or safety and therefore was more trade restrictive than necessary. In this case the complaining country

\footnotetext{
${ }^{13}$ In our dataset, the $40 \%$ of total bilateral STCS are raised on HS4 headings belonging to the agriculture sector. For this reason, our estimation sample covers also the agriculture sector.

${ }^{14}$ See https://www.wto.org/english/tratop_e/dispu_e/cases_e/ds231_e.htm

${ }^{15}$ See document G/TBT/N/CHN/20/Rev.1.
} 
asked for scientific evidence on the basis of China's imposition of this measure. This case remains unsolved over our period of observation. Another example of STC raised by the EU against China involved the beverage sector, specifically wine. Notified in May 2006, this measure specifies the terminologies, definitions, technical requirement and labelling of imported wines. In particular, this measure fixed a level of sulphur dioxide consistently below the level imposed by international standards. The EU delegation considered such measure being unnecessarily restrictive for their wine exporters. ${ }^{16}$

Such concerns in the WTO TBT committee are common, suggesting that TBTs represent impediments to trade without necessarily protecting consumers in the imposing countries. For this reason, in the present paper we do not discuss the welfare effects of TBTs related with consumer protection in the imposing country; we simply observe a potential negative welfare effect in the imposing country due to the reduction in the number of firms and in the average productivity of firms complying with the standard (anti-competitive effect of TBTs). We use STCs on TBT measures as examples of increases in trade costs.

\subsection{French firm-export data}

Individual export data on French firms are provided by French Customs for the 1995-2007 period. ${ }^{17}$ We focus on the 1997-2007 period since we lose the two starting years after calculating the firm's exit probability and the inclusion of lagged variables in the estimations (for details see section 4). The French firm dataset includes export records at firm, product, and market levels for all French exporters. ${ }^{18}$ Although the dataset classifies product categories using the Combined Nomenclature at 8 digits (e.g. CN8 is an 8-digit European extension of HS6 comprising some 10,000 product categories) we aggregate export data at HS-4 level for coherence with the STC TBT dataset.

Since the EU is considered a single country in WTO committees, we restrict our firm-level sample to extra-EU export flows. ${ }^{19}$ Given the huge number of observations and the need to

\footnotetext{
${ }^{16}$ See document TBT/N/CHN/197.

${ }^{17}$ These data are subject to statistical confidentiality and have been acceded at CEPII.

${ }^{18}$ We consider legal units, as defined by their administrative identifier.

${ }^{19}$ We consider only export flows towards extra-EU 27 countries. Eastern European Countries (and other new
} 
square the dataset to compute a firm exit dummy, we select a subsample of firms and relevant destination countries. First, we calculate total export flows by destination market, retaining markets with above-10 percentile exports. Destinations in the bottom 10 percentile of total French exports can be considered less relevant for French exporters. Then, we retained firmHS4-destination units with positive exports at least four times during the period 1995-2007 in order to reduce bias from occasional exporters (churning). ${ }^{20}$

Figure 1 depicts the number of exporters (firm-HS4 combinations) by extra-EU destination country in 2005. As expected, the main destinations are the US and Switzerland which are respectively among the most attractive and close markets for French firms. Figure 2 shows the positive correlation between the number of exporters and market attractiveness (as GDP and the GDP/distance ratio); the US, Switzerland, and Japan are the most attractive markets for French exporters.

The main advantage of individual exporter data is their high quality and the possibility to see clearly whether TBTs affect the intensive/extensive margins of trade, the dynamics of exit from foreign markets, and firms' export price setting. We would also like to control for firm characteristics when determining the effect of TBTs. However, since we have no information on turnover, employment, or capital for the universe of French exporters, we rely on export-based measures of firm characteristics. ${ }^{21}$

Using transaction level data for the universe of French exporters, we can provide some descriptive evidence on the specificity of multi-destination firms. We classify each firm based on quartiles of the number of destinations without STCs raised by EU on TBT (i.e. TBT-free for simplicity) served by the firm in $1995-k_{i, s, 1995 .}{ }^{22}$ Table 5 shows that firms

EU members) are consistently excluded from the sample throughout the period 1995-2007.

${ }^{20}$ As a robustness check we run baseline regressions with a different definition of churning. We retained firm-HS4-destination units with positive exports at least two times during the period 1995-2007, but dropped firm-HS4-destination units that stop exporting after the raising of a TBT concerns and re-exported the year after with the TBT still in force (these are real churning). Results for this robustness check are reported in the On Line Appendix table B5.

${ }^{21}$ Data on French firm characteristics are available only for firms with more than 25 employees. Over $50 \%$ of exporting firms have fewer than 20 employees. To correctly account for the extensive margin of exports, we do not use data on French firm characteristics.

${ }^{22}$ We use the number of TBT-free destinations to be coherent with our theoretical framework described in the introduction and with the core empirical exercise presented in the next section. 1995 data are used to reduce 
with number of destinations, $k_{i, s, 1995}$, above the 90 th percentile of the $k_{i, s, 1995}$ distribution (which corresponds to 17 TBT-free destinations) ${ }^{23}$ account for the highest share of French exports: they represent 32\% and 33\% of total French exports in 2000 and 2005 respectively. Figure 3 depicts the empirical distribution of export value (in log) for incumbent firms in destination with and without stringent TBTs. The existence of a TBT (when stringent) modifies the toughness of the competition, so incumbent firms in TBT imposing countries enjoy reduced competition and (on average) export more - the distribution of export values in TBT imposing countries lies on the right (red continuous line in the figure). This effect seems to be stronger for multi-destination firms (dashed lines in figure 3 ). To stress the peculiarity of multi-destination firms, table 6 presents illustrative regressions to compare the export performances of multi-destination firms (having $k_{i, s, 1995}>17$ ) to the rest of French firms over the period 1997-2007. The variables listed on the left are the dependent variables in these regressions; the coefficients refer to a dummy variable that is equal to 1 for multi-destination firms. The unit of observation is firm-product(HS4)-destination-year. It emerges that multi-destination firms export more, and more intensively (export value per item exported within the HS4 category); they also are more reluctant to exit from a market, and (on average) they charge a lower export price than the rest of exporting French firms.

\section{Empirical Strategy}

The main objective of the paper is to study the asymmetric effect of stringent TBTs (as reflected by STCs on TBT measures) on the export margins of heterogeneous firms, with a focus on the multi-destination status of firms. Recall that, for coherence with the theoretical framework discussed in introduction, in our empirical exercise a firm is the combination between the legal unit (identified by its administrative identifier) and the HS-4 category exported. We want to test a series of theoretical predictions suggested by trade theory with heterogeneous firms and destinations. The first prediction is that stringent TBTs, by increasing trade costs, will push firms out of the market imposing the TBT. Multi-destination 
firms $^{24}$ will consider reorienting their exports towards TBT free markets for which they have already paid the fixed cost of entry. Our second prediction is that multi-destination exporters will also look for new markets as a result of stringent TBTs. They will expand their geographical scope towards TBT free markets and bear the fixed costs of entry into new destinations. In the following we test these two predictions using the data on the universe of French exporters. Then, we compute aggregate trade elasticity and structurally decompose it into the two components identified by Chaney (2008), i.e. extensive vs intensive margin channel. This decomposition helps in clarifying the nature of the trade cost imposed on firms in relation to TBT concerns.

\subsection{Trade diversion within the initial geographical scope of incumbent exporters}

In this section we test our first prediction by estimating the effect of stringent TBTs on both the exit probability and firm's participation in the export market. The heterogeneous reaction of exporters to a common shock in trade costs is expected to be shaped by their multi-destination status. Indeed, multi-destination firms, having lower diversion cost can switch destination countries more easily than other firms: the sunk cost of entering alternative destinations has already been paid. In particular they can simply drop the destination country having a STC on TBT (drop strategy) and reorient their exports towards destinations without STCs on TBT (for simplicity here indicated as TBT-free destinations). ${ }^{25}$ We also examine the extent to which TBTs affect the intensive margin and the export prices of incumbent firms.

In our empirical strategy the average effect of a stringent TBT is captured by a dummy, $T B T_{s, j, t}$, reflecting the existence, at time $t$, of an ongoing (unresolved) TBT concern in product category $s$ raised by the EU against an importer country $j .{ }^{26}$ To investigate how TBT

\footnotetext{
${ }^{24}$ Firms with wide portfolio of destinations are expected to have lower diversion cost.

${ }^{25}$ As explained in section 3.1, in the econometric exercise we use only STCs raised by EU on TBT.

${ }^{26}$ Notice that the $T B T_{s, j, t}$ dummy turns to zero when the TBT concern is solved. The average duration of a TBT concern (across products and destinations) is 1.6 years while the median is 1 year. In the On Line Appendix figure B2 we plot the average duration of TBT concerns by imposing country. We make the implicit assumption that a STC is raised the same year of the underlying TBT measure. As a robustness check, we use a specification with lagged TBT concern controlling for the fact that a TBT concern can be raised at the WTO the year after the imposition of the underlying TBT measure. Results using lagged TBT dummy are
} 
concerns shape the adjustments of multi-destination exporters we interact the TBT dummy with the multi-destination status of the firm in the starting year $1995-l_{i, s, 1995}\left(k_{i, s, 1995}>\bar{k}\right)$. 27 Multi-destination status is a dummy equal to 1 if the number of TBT-free destination markets served by firm $i$, for product $s$ in $1995-k_{i, s, 1995}$ - is above a certain threshold $\bar{k}$. We use the top-10th percentile of the distribution of $k_{i, s, 1995}$ as a threshold $\bar{k}$. This threshold, given the observed distribution of $k_{i, s, 1995}$, corresponds to 17 destinations. So, our dummy $I_{i, s, 1995}\left(k_{i, s, 1995}>\bar{k}\right)$ is equal to 1 if the number of TBT-free destinations in 1995 is greater than $17 .{ }^{28}$

The multi-destination status of the firm is identified by using the number of TBT-free destinations in order to capture the idea that firms reorient their exports towards destinations (already served) without STCs on TBT. However, the imposition of a TBT in a specific country might have general equilibrium consequences affecting the degree of competition (price index) in third countries. This might affect the preference of the multi-destination firms for diverting trade towards TBT-free destinations. So, as a robustness check, we use the total number of destinations served by the firm to compute the multi-destination dummy $l_{i, s, 1995}\left(k_{i, s, 1995}>\bar{k}\right)$. Results for this robustness check are reported in the last column of all the baseline regressions.

So, the estimated equation is:

$$
\begin{aligned}
y_{i, s, j, t}= & \alpha+\beta_{1} T B T_{s, j, t}+\beta_{2}\left(T B T_{s, j, t}\right) * l_{i, s, 1995}\left(k_{i, s, 1995}>\bar{k}\right)+\beta_{3} l_{i, s, 1995}\left(k_{i, s, 1995}>\bar{k}\right) \\
& +\beta_{4}\left(T B T_{s, j, t} * \ln (\text { size })_{i, 1995}\right)+\beta_{5}\left(T B T_{s, j, t} * \text { Domestic }_{i, s, 1995}\right) \\
& +\beta_{6} L n(\text { tariff }+1)_{s, j, t}+\phi_{H S 2, t, j}+\mu_{i}+\varepsilon_{i, s, j, t}
\end{aligned}
$$

available upon request and confirm our main results.

${ }^{27}$ We used the distribution of TBT-free destinations in 1995 to reduce any endogeneity concerns related to the number of TBT-free destinations served by the firm in a given year.

${ }^{28}$ The top 10th percentile of the $k_{i, s, 1995}$ reflects the "exceptional" nature of multi-destination firms (or global firms). Alternatively, as a robustness check, in tables B1 - B4 in the On Line Appendix we use the top 5th and 1st percentiles of the $k_{i, s, 1995}$ distribution as a threshold for the dummy $I_{i, s, 1995}\left(k_{i, s, 1995}>\bar{k}\right)$. 
where the subscripts $i, s, j$, and $t$ respectively denote firm, HS 4-digit product category (or 2-digit sector if HS2), destination country, and year.

Our dependent variables are: (i) a dummy variable for a firm exiting a certain market (a dummy for no exports by the firm in years $t$ and $t+1$ but exports in the previous 2 years); (ii) a dummy variable for firm-product export participation (the extensive margin of exports), meaning positive trade flows into a certain product-destination market combination; (iii) the firm's export values (in logs) to capture the intensive margin of trade; ${ }^{29}$ and (iv) the price of exported goods (in logs), proxied by unit export values. ${ }^{30}$

Our explanatory variables are the $T B T_{s, j, t}$ dummy, and its interaction with the multi-destination status of the firm, $I_{i, s, 1995}\left(k_{i, s, 1995}>\bar{k}\right) .{ }^{31}$ Notice that multi-destination exporters are also large and high-productive firms. So, in order to isolate the multi-destination status from the firm size effect, in equation (1) we control for firm size and its interaction with the TBT dummy. Since we do not have exhaustive information on French exporters' balance sheets, we calculate the size variables in terms of exports and not total sales. ${ }^{32}$ We define this variable as: $\operatorname{In}(\text { size })_{i, 1995}=\sum_{s \subset S} \sum_{j \subset J}$ exports $_{i, s, j, 1995}$. We take the size of the firm in 1995 in order to avoid any endogeneity concerns related to the firm size proxy.

There is an important issue related to the structure of our data that is worth mentioning. In order to compute the exit dummy, we squared the dataset and we track a given firmproduct-destination combination over the entire period. So, when counting the number of TBT-free destinations in 1995, we might have zero for firms exporting only in destinations with TBT and also for firms that did not export to any destination in 1995 but started exporting afterwards in our dataset. In 1995, these firms are pure domestic firms which

\footnotetext{
${ }^{29}$ The dependent variable in this regression includes only positive trade values.

${ }^{30}$ Despite the dichotomous nature of some of our dependent variables, we estimate equation 1 via OLS. To avoid the incidental parameter problem due to the sizable set of fixed effects we include in all regressions, we rely on simple linear probability model (LPM) rather than on non-linear probit (or logit) models. In addition, LPM provides simple direct estimates of the sample average marginal effect.

${ }^{31}$ In this way the coefficient on the TBT dummy is the effect of TBTs for firms with less than 17 TBT-free destinations. However, having one of ten destinations can make a difference. So as a robustness check in the On Line appendix Table B7 we use a binned model where the effect of TBT is estimated by quartile of number of TBT-free destinations. Our results are confirmed.

${ }^{32}$ The empirical literature shows that export values are a good proxy for the firm's overall size: big exporters are usually larger and more-efficient than non-exporters (see Mayer and Ottaviano (2008))
} 
become exporters later on, i.e. less experienced firms. Although we have no a priori on the effect of TBTs for these firms, we need to control their dynamics when a TBT is imposed. We do so by simply interacting the TBT variable with a dummy equal to 1 if the firm-product combination was purely domestic in 1995 - Domestic $c_{i, s, 1995}$, and zero otherwise. In order to isolate the effect of TBT concerns from traditional tariff protection we control also for applied tariffs at the product level $\left(\operatorname{Ln}(\operatorname{tariff}+1)_{s, j, t}\right) .{ }^{33}$

Finally we add two sets of fixed effects. First, a set of firm fixed effects $\left(\mu_{i}\right)$ to control for firm-specific and time-invariant unobserved characteristics which might affect the trade performance of exporters. Second, a set of three-way fixed effects (HS2-Destination-Year) $\phi_{H S 2, t, j}$, to control for country-time-HS2-level varying factors such as business cycles, importdemand shocks and multilateral trade resistance (as highlighted by Head and Mayer (2014)) which might affect trade. These three-way fixed effects control also for the geographic orientation of French exports. In addition, HS2-destination-year fixed effects control also for measures imposed by a country in response to a negative domestic shock in a given sector. ${ }^{34}$

An important potential issue to address is endogeneity. The inclusion of firm and countryHS2-time fixed effects drastically reduces any endogeneity concerns due to the omitted variables bias. Reverse causality arises if the government of a certain destination market introduces a TBT measure in response to high levels of imports from a specific French firm (and then a STC is raised by the EU against this measure). This is a remote possibility, and especially if we consider that we use TBT concerns raised by the EU as a whole (and not STCs raised specifically by France). However, it might be the case that a STC is raised by the EU if a French firm (with high lobby power) complains about a specific measure imposed in a given product-destination. ${ }^{35}$ We account for this potential endogeneity bias in two steps.

\footnotetext{
33 The tariff data come from the TRAINS database. Since TRAINS provides tariffs in percentage points (i.e. $10 \%$ ad-valorem tariff listed as 10), we divide tariff by 100 and then compute the price equivalent transformation $\log ($ tariff +1$)$

${ }^{34}$ As a robustness check, in the On Line Appendix table B6 we include also destination-products (HS4) fixed effects controlling for the sensitivity of a specific product-destination to be object of a STC at the TBT committee of the WTO. Our main results hold.

${ }^{35}$ To (partially) reduce this concern, in a first robustness check we use the STCs raised by any country in the world rather that by EU only. Namely, we consider also STCs raised by extra-EU countries, which are less subject to the endogeneity concern described above. Results are reported in the Appendix table A2. As a further robustness check we simply drop top-exporting firms into a given product-destination (i.e. firms with
} 
First, we introduce a variable controlling for the firm's visibility in a given destination $j$, HS2 chapter in 1995 - Visibility $i, H S 2, j, 1995$. This is calculated as (the logarithm of 1 plus) the share of exports of a firm in a certain market and HS2 sector over total French exports in the same market and sector. This is also introduced as an interaction term with the TBT concerns variable. If a government imposes a TBT to curb the exports of a specific firm, then this exporter will suffer relatively more from TBT imposition. Our estimation results show that this is never the case: highly visible firms are not targeted by the imposition of TBT (so they do not have specific interest in pushing the EU to raise a STC at the WTO). ${ }^{36}$

Second, we use an Instrumental Variable approach (2SLS). Our instrument is a dummy IV $T B T_{j s t}$ which is equal to 1 if two conditions hold: (i) if country $j$ has an active TBT concern on at least one product other than $s$ and (ii) if at least one third country (other than $j$ ) has an active TBT concern over product $s$ at time $t$. The idea is that the probability of an active TBT concern from country $j$ over product $s$ is positively correlated with the activism of country $j$ in imposing a measure (on other products than $s$ ), and with the sensitivity of product $s$ to being protected by a third country. The imposition of TBT by third countries (other than $j$ ), and the imposition of TBT on a product other than $s$ are likely to be exogenous with respect to French exports into a specific js combination. We then interact the instrument IV TBT $T_{\text {jst }}$ with firm specific characteristics (size, domestic and multi-destination status) to instrument all the interactions described in equation 1 . The relevance of our instrument is displayed at the bottom of table 11 which reports the first stage coefficients of interest. For example, the coefficient of IVTBT jst refers to a first stage estimation with the TBT dummy as a dependent variable. Similarly, the coefficient of the interaction between $I V T B T_{j s t}$ and $I_{i, s, 1995}\left(k_{i, s, 1995}>\bar{k}\right)$ refers to the first stage estimation of the interaction between TBT and $I_{i, s, 1995}\left(k_{i, s, 1995}>\bar{k}\right)$ as a dependent variable. In the last rows of table 11 we also report the joint F-stat for the first stage which is above (or slightly below) 10, implying that the

export value in 1995 above the $99^{\text {th }}$ ) who are more likely to complain in presence of a stringent TBT. Results reported in table $\mathrm{A} 3$ hold.

${ }^{36}$ As a further way of reducing reverse causality concern we estimate our regressions lagging the TBT variable by one year: there is a small chance that a concern raised at $t-1$ is driven by exports at time $t$. Results using lagged TBT dummy are available upon request and confirm our main results. 
instruments are not weak. ${ }^{37}$ In the On Line Appendix table B8, as a further robustness, we run a 2SLS specification with a different instrumental variable: a dummy equal to one if at least a third country $(k \neq j)$, belonging to the same geographic region as $j$, has an active TBT STC on product $s$. The structure of the table does not change and our main results hold with good first stage regression statistics. ${ }^{38}$

\subsection{Trade diversion beyond the initial geographical scope of incumbent exporters: new markets}

In presence of TBT concerns in a given destination country, instead of simply exiting the market (drop strategy) or exit and reorient sales towards existing destinations, the firm might both exit the market and add a new TBT-free destination (add strategy). This happens as soon as the fixed costs of exporting into a new destination are below the costs of staying in the market imposing the TBT, and complying with this stringent regulation, or paying the incremental cost of reaching new customers in existing destinations. In this case we should see a positive effect on the number of new destinations countries at $(t+1)$.

To investigate this second type of adjustment, we collapse the dataset for firm-product-year so that for each firm-product combination we can track the total number of new TBT-free destinations. For each firm-product we can compare the set of destinations at time $t$ with those at time $t-1$, and count the number of new TBT-free destinations. We use the (log of the) number of new TBT-free destinations by firm-product at time $t$ as the dependent variable in the following estimating equation: ${ }^{39}$

\footnotetext{
${ }^{37}$ The problem of weak instruments could be present in the estimations in columns (6) and (8) where the joint F-stat is around 7; thus, the results of these two estimations should be interpreted with caution. Notice that usually the low joint F-stat is due to the inclusion of big sets of fixed effect and conservative clustering of standard errors which might be the case here.

${ }^{38}$ Notice that in this case, in order to have a powerful first stage regression we did not cluster the standard errors at destination-HS4-year (as we do in all other specifications). This does not represent a problem since we are interested here in the interaction between TBT and the multi-destination status of the firm which is firm-destination-HS4-year specific.

${ }^{39}$ We keep the firm-product combinations with zero new destinations by computing the dependent variable as follows:
}

$$
y_{i, s, t}=\max \left(0 ; \ln \left(y_{i, s, t}\right)\right)
$$




$$
y_{i, s, t}=\alpha+\beta_{1} T B T_{i, s, t-1}+\beta_{2} k_{i, s, t-1}+\beta_{3}\left(T B T_{i, s, t} * k_{i, s, t-1}\right)+\phi_{s, t}+\mu_{i}+\varepsilon_{i, s, j, t},
$$

The main explanatory variable, $T B T_{i, s, t-1}$, is a dummy that is equal to 1 if the firm exported a given product to at least one destination having STC on TBT at (t-1). We also include as a control the number of TBT-free destinations served by firm $i$ on product $s$ at time $t-1, k_{i, s, t-1}$. This approximates the multi-destination status of the firm at time $t-1$. We interact the above two mentioned variables to test the peculiar behavior of multi-destination firms facing TBT concerns in terms of their destination portfolio. Finally, we include firm and product-by-year fixed effects to control for firms specific characteristics and any product specific unobserved shock.

\section{Results}

\subsection{The Effects of TBT on firms' margins of trade}

Results for the estimated equation 1 are reported in tables 7-10 for respectively the exit probability, the extensive margin, the intensive margin and the price charged (proxied here by the unit value of the firm-HS4-destination-year flow).

Table 7 presents the results for the firms' exit probability. The mean effect of the presence of an active TBT concern within an HS4 is to push firms out of the market imposing this measure (column 1). This effect holds also after controlling for the interaction between TBT and firm size, and for the specific behavior of less experienced firms (column 2). Consistent with the above reasoning, in column 3 we observe that this effect is magnified for multidestination exporters (i.e. firms which in 1995 exported towards 17 or more TBT-free destinations): the coefficient of the interaction term between TBT and $I_{i, s, 1995}\left(k_{i, s, 1995}>\bar{k}\right)$ is positive and significant in column 3. This result holds after controlling for the firm's visibility and its interaction with TBT (column 4). The fact that high visibility firms do not suffer from imposition of a TBT more than other firms, suggests the absence of any reverse 
causality concerns. So we can conclude that stringent TBTs (on average) push firms out of the market with this effect magnified for multi-destination firms. This result is robust to a different definition of the multi-destination status of the firm (based on the number of total rather TBT-free destinations) - see column $5 .{ }^{40}$

Table 8 shows the effect of TBT concerns on the extensive margin of French exporters (participation). Columns 1 and 2 show that the presence of TBT concerns reduces the probability of exporting into the destination imposing the measure on the considered HS4 product category. This result is robust across all the specifications reported in table 8 . In column 3 we show that the mean negative effect of a TBT concern is exacerbated for multi-destination firms: these exporters are even less inclined than other firms to export to destination countries with active TBT concerns. Comparing the stringency of the TBT (as revealed by active concerns) and the related cost of diverting trade, multi-destination exporters are inclined to divert their sales either to other destinations already present in their market portfolio, or to new TBT-free destinations (we discuss this in full in section 5.2). However, as already noted, the interaction between the TBT dummy and the multi-destination status of the firm might capture the effect of TBT by firm size. So in columns 2-4 we include the interaction between the TBT dummy and the firm size. The sign of this interaction is negative and significant, suggesting that big firms are less inclined to manage stringent TBTs, however the sign of the interaction between TBT and $I_{i, s, 1995}\left(k_{i, s, 1995}>\bar{k}\right)$ remains negative and significant. This confirms the magnified impact of TBT on the participation of multi-destination firms. Finally, column 4 includes the interaction between TBT and visibility of the firm. The coefficients of interest hold with the expected sign, and the interaction between TBT and visibility is positive and significant. This means that high visibility firms gain from the imposition of a TBT, confirming the absence of reverse causality. ${ }^{41}$ So we conclude that the presence of TBT concern reduces the probability of exporting into the destination imposing

\footnotetext{
${ }^{40}$ This result is also robust to the inclusion of HS4-destination fixed effects. See table B6 in the On Line Appendix.

${ }^{41}$ As discussed above, reverse causality concerns arise if government imposes TBT measures to face imports from high visibility firms. In this case, high visibility firms should suffer the imposition of TBTs with a larger extent, i.e. negative interaction between TBT and firm visibility. Here we find the opposite effect confirming the absence of reverse causality issue.
} 
the measure, with a magnified effect for multi-destination firms. ${ }^{42}$ The result holds when we use the alternative definition of multi-destination status dummy (see columns 5 ). ${ }^{43}$

Table 9 presents the results for the firm's intensive margin. The presence of a TBT concern has a positive and significant effect on the intensive margin of (incumbent) multi-destination firms only - see positive interaction between TBT and $I_{i, s, 1995}\left(k_{i, s, 1995}>\bar{k}\right)$ in columns 3 and $4 .{ }^{44}$ This suggests that (stringent) TBTs act as a barrier to entry reducing competition in the imposing country to the benefit of surviving exporters. Multi-destination firms (on average) exit from the market imposing the measure; but those choosing to comply with the imposed standard benefit from reduced competition.

Because stringent TBTs add a further cost of exporting, we expect a positive average effect of TBT on the export price for firms complying with the standard. Table 10 presents the estimation results for the export prices of complying firms. ${ }^{45}$ Coherent with the above reasoning, we obtain a positive and significant coefficient of the TBT dummy.

Finally, table 11 presents the results of the 2SLS estimation. The results for the exit probability (columns 1 and 2) show that stringent TBTs push average firms out of the market, with this effect magnified for multi-destination firms. Multi-destination firms are less inclined to cope with TBTs (columns 3 and 4), but conditioned on deciding to adapt to the standard, they enjoy the reduced competition (columns 5 and 6). ${ }^{46}$ We got the same results by using the alternative instrumental variable described in section 4 - see table B8 in the On Line

\footnotetext{
${ }^{42} \mathrm{We}$ find a null effect of tariffs on the extensive margin (participation). Notice that here tariffs are meant as simple control variable, and a proper estimation of the tariff elasticity would imply different empirical specification. However, tariffs are increases in the variable export cost and so are expected to affect only the intensive margin of exports (as shown in table 9).

${ }^{43}$ The result holds also after including HS4-destination fixed effects - see On Line Appendix B6. However, with the inclusion of HS4-destination fixed effects the coefficient on tariff switches to positive. This is probably due to the selection bias: only more productive firms are able to serve destination-HS4 with increases in tariffs (notice that the inclusion of HS4-destination fixed effect implies the identification of tariff on time variation only).

${ }^{44}$ This result is coherent with the findings in Bao and Qiu (2012).

${ }^{45}$ Recall that we do not observe the actual prices charged by firms but use Trade Unit Value as a proxy.

${ }^{46}$ The last rows of table 11 report the first stage results for the coefficients of interest, and allow us to conclude that our instruments are highly relevant. The F-stat reported in the last row of the table 11 suggests a problem of weak instrument in column 6 and 8 only, where the F-stat is about 7 - below the rule of thumb value of 10 . However, low joint F-stat may be due to the inclusion of big sets of fixed effect and conservative clustering of standard errors.
} 
Appendix. ${ }^{47}$

\subsection{The dynamics of multi-destination firms}

The evidence reported in section 5.1 suggests peculiar behavior of multi-destination firms facing TBT concerns: the presence of a stringent TBT increases the exit probability of firms and especially multi-destination firms (which have larger portfolios of destinations). In this sub-section we develop this line of reasoning further: we study the adjustment of firms at the extensive margin enabled by the inclusion of new destinations in their geographic portfolios. Specifically, we investigate whether the firm enters new markets after exiting from the TBT imposing market.

The results for the estimation of Equation 2 are reported in table 12. As expected, when a firm faces a TBT concern on product $s$ in (at least) one of its destinations at ( $t-1$ ), she will ship the particular HS4 product category to new - TBT-free - destinations in $t$. We show that the number of new TBT-free destinations is affected positively if the exporter is hit by a stringent TBT a time (t-1) for the same HS4 product category in an existing destination (column 1-8). This effect is magnified for those firms with multiple TBT-free destinations at (t-1) - see columns 3, 4. As a robustness check, we replicate the same type of estimations using simply the number of destinations at (t-1) as a proxy for the multi-destination status of the firm; the results do not change (see columns 5-8).

This result is in line with our hypothesis: in the presence TBTs, exporters will balance the cost of complying with this regulation against the fixed cost of entering a new market, and will make the decision to serve the new market if the regulation is stringent (as revealed by the existence of a STC). More productive exporters already serving several destinations, are shown to be more likely to make the decision to enter a new market. This result suggests the presence of economies of scope in terms of future prospects, distribution networks, and product branding.

\footnotetext{
${ }^{47}$ With the alternative IV we got the same results for the extensive and intensive margin, but a "puzzling" negative effect on the price charged by multi-destination firms in the imposing country.
} 


\section{Implications at the aggregate level}

So far we provided micro-level evidence supporting the fact that stringent TBTs push firms out of the imposing market, with a magnified effect for multi-destination firms (which are less inclined to meet stringent technical standards because they have the option of redirecting their sales to existing or new alternative destinations) - see table 7. Multi-destination firms can switch destination countries more easily than other firms, and after imposition of a TBT may even move to new TBT-free destinations. At the same time, we found that multidestination firms complying with the measure benefit from TBTs at the intensive margin see table 9 . In this section we focus on aggregate export flows and show the heterogeneous macro-level effect of TBTs on sectors with different densities of multi-destination firms and on sectors with different distribution of exporters' size and productivity. Firstly, following our firm-level evidence, in sectors with a high share of multi-destination firms, the aggregated effect of TBT is expected to be magnified on the extensive margin and attenuated on the intensive margin.

Secondly, in a model with heterogeneous firms and a CES demand function, Chaney (2008) argues that the aggregate trade cost elasticity is exacerbated in more homogeneous sectors, where more output is concentrated among smaller and less productive firms. ${ }^{48}$ Thus, in testing the macro-level effect of TBTs we have to control for the heterogeneity of sectors in terms of firm size distribution - here inversely approximated by the Pareto shape parameter of firm size distribution. ${ }^{49}$

To test these predictions, we aggregate our dataset at product-destination-year level and estimate the following regression:

\footnotetext{
${ }^{48}$ See section 3 in Chaney (2008) for further details and derivation of this prediction.

${ }^{49}$ This mimics what we have done in the firm level evidence by controlling for the size of the firm and its interaction with TBT dummy.
} 


$$
\begin{aligned}
y_{s, j, t}= & \alpha+\beta_{1} T B T_{s, j, t}+\beta_{2}\left(T B T_{s, j, t}\right) * \text { MultiDestShare }{ }_{H S 2, j, t}+\beta_{3} \text { MultiDestShare }_{H S 2, j, t} \\
& +\beta_{4}\left(T B T_{s, j, t}\right) * \text { ParetoParameter }_{H S 2, j, t}+\beta_{5} \text { ParetoParameter }_{H S 2, j, t} \\
& +\beta_{6} L n(\text { tariff }+1)_{s, j, t}+\phi_{s t}+\phi_{j t}+\varepsilon_{s, j, t}
\end{aligned}
$$

where the subscripts have the same meaning as before. The dependent variable $y_{s, j, t}$ is in turn: (i) the total export value in each product-destination cell (in log), (ii) the number of exporting firms in the product-destination cell (in log, the extensive margin channel), and (iii) the average export per firm in a product-destination cell (in log, the intensive margin channel). $T B T_{s, j, t}$ is a dummy variable indicating the presence of an active TBT concern in a given product $s($ HS4 $)$ and destination $j$, and $L n(\operatorname{tariff}+1)_{s, j, t}$ is the tariff level faced by French firms when exporting product $s$ to destination $j$.

To control for the heterogeneity in firm size distribution, we interact the TBT dummy with the estimated shape parameter of the Pareto distribution of firms size in each sector HS2destination cell (time invariant). ${ }^{50}$ We use the QQ estimator as in Head et al. (2014) to recover sector-destination specific Pareto shape parameters. The $Q Q$ estimator basically minimizes the sum of the squared errors between the theoretical and the empirical quantiles and gives an indirect measure of the estimated Pareto shape parameter which is easily reversed by assuming an elasticity of substitution $\sigma=4$ (as in Head et al. (2014)). ${ }^{51}$ As the shape parameter of the Pareto distribution is an inverse measure of the heterogeneity of the sector for a given destination, we expect a negative sign on its interaction with TBT.

The variable MultiDestShare is the share of multi-destination exporters over the total number of exporting firms in the sector(HS2)-destination cell. This variable provides information on the presence of multi-destination firms in the HS2 sector for a given destination country. ${ }^{52}$

\footnotetext{
${ }^{50} \mathrm{As}$ in the firm level evidence, we approximate the firm size with firm's total exports (across product and destinations).

${ }^{51}$ See appendix section 1 and Head et al. (2014) for details of the theoretical and empirical quantiles of the Pareto distribution and the QQ estimator. The Pareto shape parameter is obtained as $\gamma=(\sigma-1) \widetilde{\gamma}$, where $\widetilde{\gamma}$ is the empirical shape parameter.

${ }^{52}$ We used the HS2-destination specific distribution in order to have a sufficiently high number of firms in a
} 
By interacting the TBT dummy with MultiDestShare we aim to capture whether the expected negative effects of TBT on the extensive (intensive) margin is magnified (attenuated) in sectors with high presence of multi-destination firms, as we would expect from firm level estimations in tables 7 and 9.

The results in table 13 support these predictions. TBT has a negative and strongly significant effect on aggregate export flows and margins: the presence of a stringent TBT reduces aggregate exports by $50 \%$ (see column 1 ), the number of active firms by $22 \%$ (see column 4) and the average export per firm by $34 \%$ (see column 7 ). Interestingly, the negative effect of TBT on total export is attenuated for product (HS4) belonging the sectors (HS2) with many multi-destination firms (column 2). However, this result vanishes when we control for the firm size heterogeneity of the sector (column 3), where the negative effect of TBT is magnified in more homogeneous sectors (where more output is concentrated among small firms). This is perfectly in line with the theoretical prediction in Chaney (2008). ${ }^{53}$

However, the presence of multi-destination firms in the sector-destination matters. Coherently with our expectations, the negative effect of TBT on the extensive margin channel (number of exporting firms) is magnified in sectors with high share of multi-destination firms - see table 13 column 5. Importantly, this result holds after controlling for the sector heterogeneity in terms firm size distribution (column 6). Concerning the average export per firm (intensive margin), we find that the average negative effect of TBT is attenuated in sectors with many multi-destination firms (see columns 8-9). This is coherent with results in table 9 showing that multi-destination firms complying to TBTs export more.

This approach can finally shed light on the nature of additional trade cost imposes by TBTs. In Chaney (2008) the aggregate trade elasticity to fixed trade costs is predicted to be driven

\footnotetext{
given sector-destination-year cell.

${ }^{53}$ Notice that, according to Chaney (2008) the trade elasticity to fixed cost is equal to $\frac{\gamma}{\sigma-1}-1$. So, with an elasticity of substitution $\sigma$ equal to 4 (as assumed by (Head et al., 2014)), and a weighted average value of Pareto shape parameter $\gamma$ equal to 1.5 (see appendix A1 for details on our estimations for $\gamma$ ), the Chaney (2008) model would suggest an elasticity equal to -0.5. This is indeed in line with our estimated coefficient for TBT in column 1 (suggesting an average $-50 \%$ of trade when a TBT is imposed). We take this feature as supporting the idea that TBTs represent increases in fixed more than a variable trade costs.
} 
by the extensive margin, with a negligible role of the intensive margin. ${ }^{54}$ In order to disentangle the aggregate effect of TBTs between the intensive and the extensive channels, we calculate the change in aggregate exports from: (i) incumbent firms - active in the market over the entire period (intensive margin channel) and (ii) the entry-exit exporters to/from a specific market (extensive margin channel). We then repeat the decomposition exercise proposed in Berman et al. (2012). We run gravity-type regressions where the dependent variable is the (log of) total export by destination-product-year for respectively incumbent and entryexit exporters firms. ${ }^{55}$ We control for bilateral-sector tariffs and include country-year and product-year fixed effects. The main regressor of interest for such gravity-type estimations is the TBT dummy. The estimated coefficients for the TBT dummy are respectively $\widehat{\beta}_{\text {incumbent }}$ and $\widehat{\beta}_{\text {entry }}$. Then we can calculate the share of total exports due to respectively incumbent and entry-exit exporters as $V_{i} / V$, where $V$ is the aggregate destination-product-year exports and $V_{i}$ is the total exports for incumbent or entry/exit firms ( $i=i n c u m b e n t$ or entry). Finally the impact of TBT on the intensive margin can be written as $\widehat{\beta}_{\text {incumbent }} *\left(V_{\text {incumbent }} / V\right)$, and similarly for the extensive margin as $\widehat{\beta}_{\text {entry }} *\left(V_{\text {entry }} / V\right)$.

The results of these calculations are reported in table 14 . As expected, the $\widehat{\beta} s$ for both incumbent and entry-exit exporters flows are negative and highly significant, but the share of total trade due to the entry-exit of firms is predominant. This implies that at the aggregate level TBT has a predominant effect through the extensive margin channel. The intensive margin channel makes a smaller contribution at the aggregate level (as expected based on our firm level estimations). Overall, these results combined with the theoretical predictions in Chaney (2008), reinforce our argument that stringent TBTs represent mainly a fixed (rather than a variable) trade cost for exporting firms.

\footnotetext{
${ }^{54}$ See section 3 in Chaney (2008)

${ }^{55}$ Here incumbent firms are continuous exporters, i.e. firms exporting over the entire period. Entry/exit firms are those with non-exporting spell in the period.
} 


\section{Conclusion}

To uncover the adjustment channels of heterogeneous exporters faced with stringent technical barriers in certain markets, we combined information on TBT Specific Trade Concerns in the WTO committee with firm level custom data for the universe of French exporters. The theory suggests that small and less productive exporters will be unable to cope with the additional fixed/variable costs of a restrictive TBT and will exit. In contrast, multidestination firms will reorient their exports towards TBT free markets (for the same HS4 category of products). The theory suggests also that a sub-sample of firms will be sufficiently productive to envisage new destinations, expand their geographical scope, and bear the associated fixed costs, provided that these markets have less stringent TBTs. These predictions are confirmed by our results. Stringent TBTs drive the average firm out of the market (reducing competition for the survivors). Multi-destination players are encouraged to redirect their exports to other destinations (free of TBT concerns), and are more likely to exit as a response to a stringent TBT - which they are less inclined to comply with. Thus, the imposition of a stringent TBT, by pushing multi-destination (high-productive) firms out of the market, reduces the average productivity of incumbent firms (i.e. the welfare of the imposing country).

In a second set of estimations we showed that for firms that opt for new TBT-free markets when faced with a stringent TBT, adjustment at the extensive margin is magnified for these initially geographically diversified exporters. This suggests the presence of economies of scope in foreign market access.

Finally, using aggregate estimations at sector-destination level, we find that stringent TBTs represent mainly increases in fixed (more than variable) trade costs, with aggregate extensive margin elasticity magnified for sectors with many multi-destination firms (more prone to divert trade towards TBT-free destinations).

To our knowledge, this is the first empirical study of the nature of the costs imposed by stringent TBTs, and the heterogeneous reactions of multi-destination exporters shaping the 
aggregate trade elasticity. We are aware that also the multi-product status of a firm might affect the firm's response to TBT imposition. We leave this for future research. 


\section{Bibliography}

Arkolakis, C. (2010). Market penetration costs and the new consumers margin in international trade. Journal of Political Economy, 118(6):1151 - 1199.

Baller, S. (2007). Trade effects of regional standards liberalization: A heterogeneous firms approach. World Bank policy research working paper, (4124).

Bao, X. and Qiu, L. D. (2012). How Do Technical Barriers to Trade Influence Trade? Review of International Economics, 20(4):691-706.

Berman, N., Martin, P., and Mayer, T. (2012). How do different exporters react to exchange rate changes? Quarterly Journal of Economics, 127(1):437-492.

Bernard, A. B., Redding, S. J., and Schott, P. K. (2011). Multiproduct Firms and Trade Liberalization. The Quarterly Journal of Economics, 126(3):1271-1318.

Chaney, T. (2008). Distorted gravity: the intensive and extensive margins of international trade. American Economic Review, 98(4):1707-1721.

Chen, M. X. and Mattoo, A. (2008). Regionalism in standards: good or bad for trade? Canadian Journal of Economics, 41(3):838-863.

Disdier, A.-C., Fontagné, L., and Cadot, O. (2015). North-South Standards Harmonization and International Trade. World Bank Economic Review, 29(2):327-352.

Disdier, A.-C., Fontagné, L., and Mimouni, M. (2008). The impact of regulations on agricultural trade: Evidence from the sps and tbt agreements. American Journal of Agricultural Economics, 90(2):336-350.

Essaji, A. (2008). Technical regulations and specialization in international trade. Journal of International Economics, 76(2):166 - 176.

Fontagné, L., von Kirchbach, F., and Mimouni, M. (2005). An assessment of environmentally- related non-tariff measures. The World Economy, 28(10):1417-1439.

Head, K. and Mayer, T. (2014). Gravity equations: Workhorse, toolkit, and cookbook. volume 4, Handbook of International Economics, chapter 4. Gita Gopinath, Elhanan Helpman and Kenneth Rogoff editors. 
Head, K., Mayer, T., and Thoenig, M. (2014). Welfare and Trade without Pareto. American Economic Review, 104(5):310-16.

Héricourt, J. and Nedoncelle, C. (2016). How Multi-Destination Firms Shape the Effect of Exchange Rate Volatility on Trade: Micro Evidence and Aggregate Implications. Working Papers 2016-05, CEPII research center.

Li, Y. and Beghin, J. C. (2012). A meta-analysis of estimates of the impact of technical barriers to trade. Journal of Policy Modeling, 34(3):497 - 511.

Mayer, T. and Ottaviano, G. (2008). The happy few: The internationalisation of european firms. Intereconomics: Review of European Economic Policy, 43(3):135-148.

Moenius, J. (2004). Information versus product adaptation: The role of standards in trade. Technical report, International Business and Markets Research Center Working Paper.

Orefice, G. and Rocha, N. (2014). Deep Integration and Production Networks: An Empirical Analysis. The World Economy, 37(1):106-136.

Wagner, J. (2012). German multiple-product, multiple-destination exporters: BernardRedding-Schott under test. Economics Bulletin, 32(2):1708-1714.

WTO (2011). The WTO and preferential trade agreements: from co-existence to coherence. WTO, Geneva.

WTO (2014). Technical Barriers to Trade. WTO, Geneva. 


\section{Tables and Figures}

Table 1 - Total notifications of TBTs per triennal review period

\begin{tabular}{rrrrrrr}
\hline \hline $1995-97$ & $1998-00$ & $2001-03$ & $2004-06$ & $2007-09$ & $2010-12$ & $2013-15$ \\
\hline 1737 & 2012 & 2096 & 2658 & 4673 & 5845 & 6150 \\
\hline \hline
\end{tabular}

Table 2 - TBT concerns by year

\begin{tabular}{cccc}
\hline \hline year & $\begin{array}{c}\text { Number of Countries } \\
\text { with at least one STC on TBT }\end{array}$ & $\begin{array}{c}\text { Number of HS4 items under } \\
\text { TBT STC in at least one country }\end{array}$ & $\begin{array}{c}\text { Average number of TBT } \\
\text { concerns per country }\end{array}$ \\
\hline 1997 & 7 & 342 & 16.19 \\
1998 & 5 & 355 & 21.84 \\
1999 & 3 & 402 & 13.35 \\
2000 & 6 & 247 & 10.03 \\
2001 & 11 & 280 & 25.58 \\
2002 & 11 & 335 & 23.61 \\
2003 & 12 & 556 & 38.10 \\
2004 & 12 & 454 & 21.06 \\
2005 & 13 & 467 & 17.61 \\
2006 & 11 & 454 & 18.00 \\
2007 & 20 & 408 & 16.16 \\
\hline
\end{tabular}

Source: Authors' calculations on the STC database, WTO

Table 3 - The top-5 motives for TBT concerns

\begin{tabular}{lcc}
\hline \hline Objective & nb occurrences across STCs & Frequency over the total specified objectives* \\
\hline Protection of Human Health or safety & 135 & $22.60 \%$ \\
Protection of the Environment & 67 & $11.20 \%$ \\
Consumer Information or Protection & 48 & $8.00 \%$ \\
Labelling & 28 & $4.70 \%$ \\
Quality & 26 & $4.30 \%$ \\
\hline
\end{tabular}

Source: Authors' calculations on the STC database, WTO

Note: Each STC has one or more objectives. One occurrence is thus the combination STC-objective.

The total number of occurrences in the dataset is 598. * The frequency reported in the column is thus the ratio between the number of occurrences of a objective over the total number of occurrences in the dataset. 
Table 4 - Number of HS4 items object of a STC in TBT by imposing country and year

\begin{tabular}{|c|c|c|c|c|c|c|c|c|c|c|c|c|c|}
\hline Country & 1996 & 1997 & 1998 & 1999 & 2000 & 2001 & 2002 & 2003 & 2004 & 2005 & 2006 & 2007 & 2008 \\
\hline Argentina & 0 & 0 & 0 & 0 & 0 & 0 & 0 & 161 & 161 & 0 & 0 & 7 & 7 \\
\hline Brazil & 0 & 0 & 158 & 0 & 0 & 167 & 3 & 5 & 2 & 2 & 0 & 10 & 15 \\
\hline Canada & 1 & 1 & 0 & 0 & 0 & 0 & 0 & 0 & 0 & 0 & 0 & 1 & 2 \\
\hline Chile & 0 & 0 & 0 & 0 & 0 & 167 & 0 & 0 & 0 & 0 & 0 & 0 & 0 \\
\hline China & 0 & 0 & 0 & 0 & 0 & 1 & 210 & 214 & 3 & 31 & 225 & 30 & 197 \\
\hline Colombia & 0 & 0 & 0 & 0 & 0 & 0 & 0 & 0 & 0 & 5 & 0 & 0 & 1 \\
\hline Ecuador & 0 & 0 & 0 & 0 & 0 & 0 & 0 & 4 & 4 & 0 & 0 & 0 & 0 \\
\hline Egypt & 0 & 2 & 166 & 166 & 3 & 0 & 0 & 0 & 0 & 0 & 0 & 0 & 0 \\
\hline European Union & 4 & 179 & 16 & 81 & 82 & 277 & 251 & 426 & 429 & 258 & 261 & 273 & 274 \\
\hline Hong Kong & 0 & 0 & 0 & 0 & 0 & 1 & 0 & 0 & 0 & 0 & 0 & 4 & 0 \\
\hline India & 0 & 0 & 0 & 0 & 0 & 2 & 171 & 10 & 14 & 0 & 7 & 18 & 14 \\
\hline Indonesia & 0 & 0 & 0 & 0 & 0 & 4 & 0 & 0 & 0 & 2 & 0 & 0 & 6 \\
\hline Israel & 0 & 3 & 0 & 0 & 0 & 0 & 0 & 0 & 0 & 0 & 0 & 1 & 1 \\
\hline Japan & 0 & 0 & 0 & 0 & 167 & 167 & 5 & 2 & 0 & 0 & 14 & 0 & 2 \\
\hline Korea & 0 & 0 & 9 & 0 & 49 & 0 & 14 & 10 & 3 & 16 & 5 & 5 & 8 \\
\hline Kuwait & 0 & 0 & 0 & 0 & 0 & 0 & 0 & 131 & 0 & 0 & 0 & 0 & 0 \\
\hline Malaysia & 0 & 0 & 0 & 0 & 0 & 0 & 0 & 0 & 0 & 18 & 0 & 0 & 0 \\
\hline Mexico & 0 & 315 & 328 & 0 & 0 & 0 & 0 & 0 & 2 & 2 & 0 & 0 & 0 \\
\hline Moldova & 0 & 0 & 0 & 0 & 0 & 0 & 0 & 0 & 0 & 0 & 0 & 2 & 8 \\
\hline New Zealand & 0 & 0 & 0 & 167 & 4 & 4 & 4 & 4 & 4 & 4 & 4 & 4 & 0 \\
\hline Peru & 0 & 1 & 0 & 0 & 0 & 0 & 0 & 0 & 5 & 11 & 5 & 5 & 5 \\
\hline Philippines & 0 & 0 & 0 & 0 & 0 & 0 & 0 & 0 & 0 & 0 & 2 & 2 & 0 \\
\hline Qatar & 0 & 0 & 0 & 0 & 0 & 0 & 0 & 0 & 0 & 0 & 0 & 8 & 0 \\
\hline South Africa & 0 & 0 & 0 & 0 & 0 & 0 & 3 & 0 & 0 & 170 & 0 & 0 & 161 \\
\hline Switzerland & 0 & 0 & 0 & 0 & 0 & 0 & 0 & 0 & 5 & 5 & 5 & 5 & 0 \\
\hline Taipei & 0 & 0 & 0 & 0 & 0 & 0 & 0 & 0 & 0 & 0 & 0 & 52 & 1 \\
\hline Thailand & 0 & 1 & 0 & 0 & 0 & 2 & 2 & 0 & 0 & 0 & 0 & 4 & 4 \\
\hline Turkey & 0 & 0 & 0 & 0 & 0 & 0 & 0 & 0 & 0 & 0 & 0 & 2 & 0 \\
\hline United States & 28 & 0 & 0 & 0 & 6 & 1 & 25 & 170 & 21 & 22 & 29 & 67 & 75 \\
\hline Uruguay & 0 & 0 & 0 & 0 & 0 & 0 & 0 & 0 & 0 & 0 & 1 & 1 & 0 \\
\hline Venezuela & 0 & 0 & 0 & 0 & 0 & 0 & 44 & 44 & 0 & 0 & 0 & 0 & 0 \\
\hline
\end{tabular}

Source: Authors' calculations on the STC database, WTO 


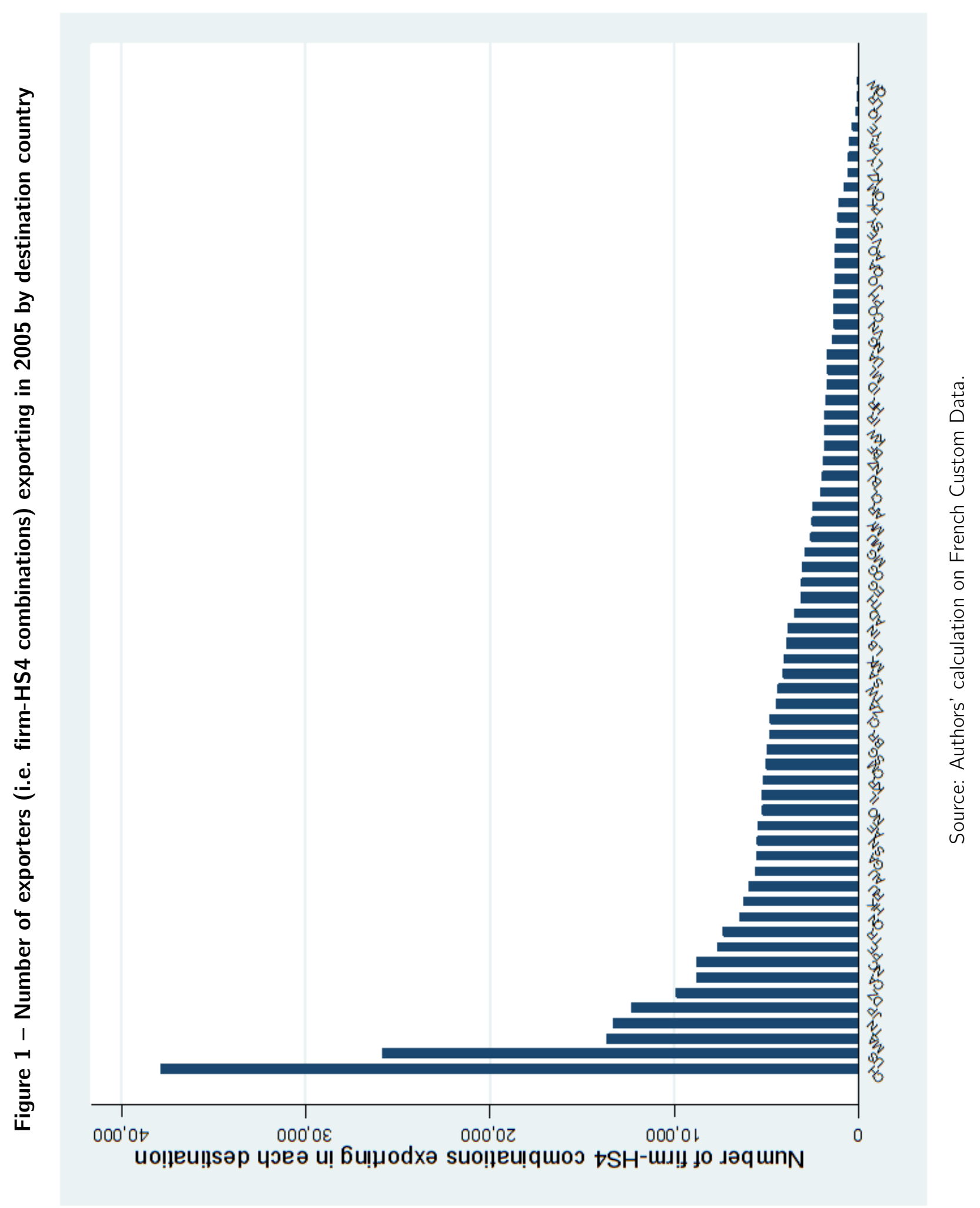


Figure 2 - Number of exporters (i.e. firm-HS4 combinations) exporting in 2005, GDP and GDP/distance in destination countries
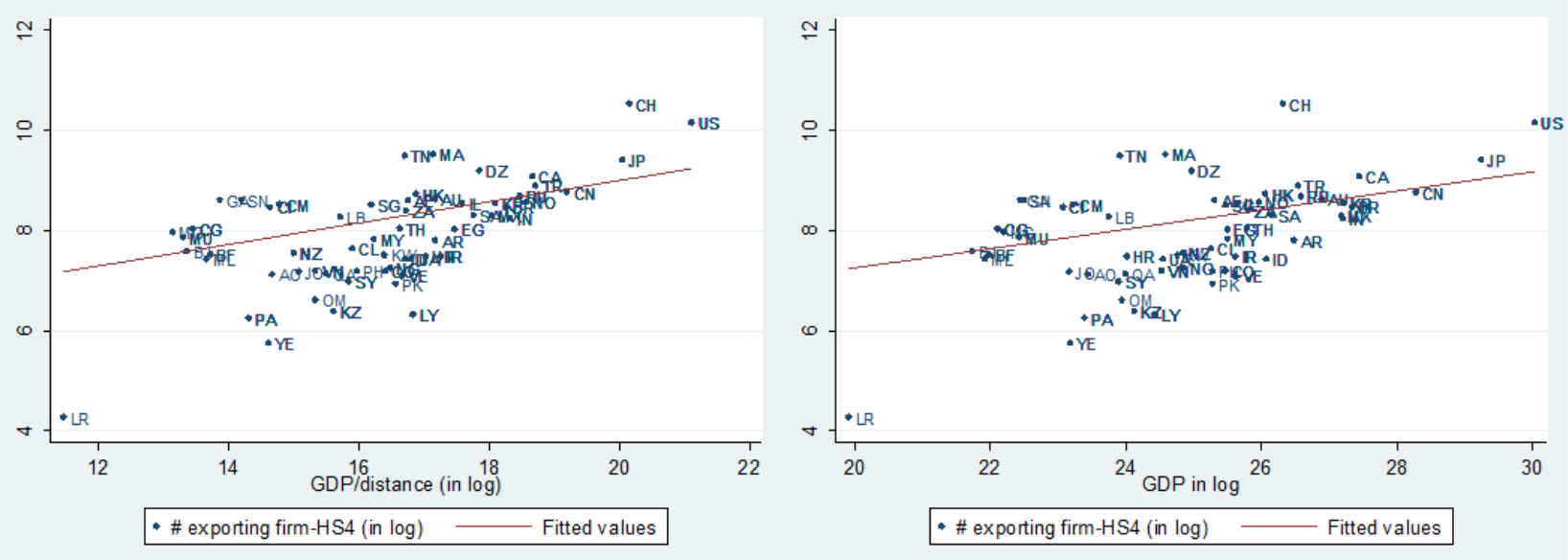

Source: Authors' calculation on French Custom Data and WB Development Indicators.

Figure 3 - Empirical distribution of export value (in log) in 2005.

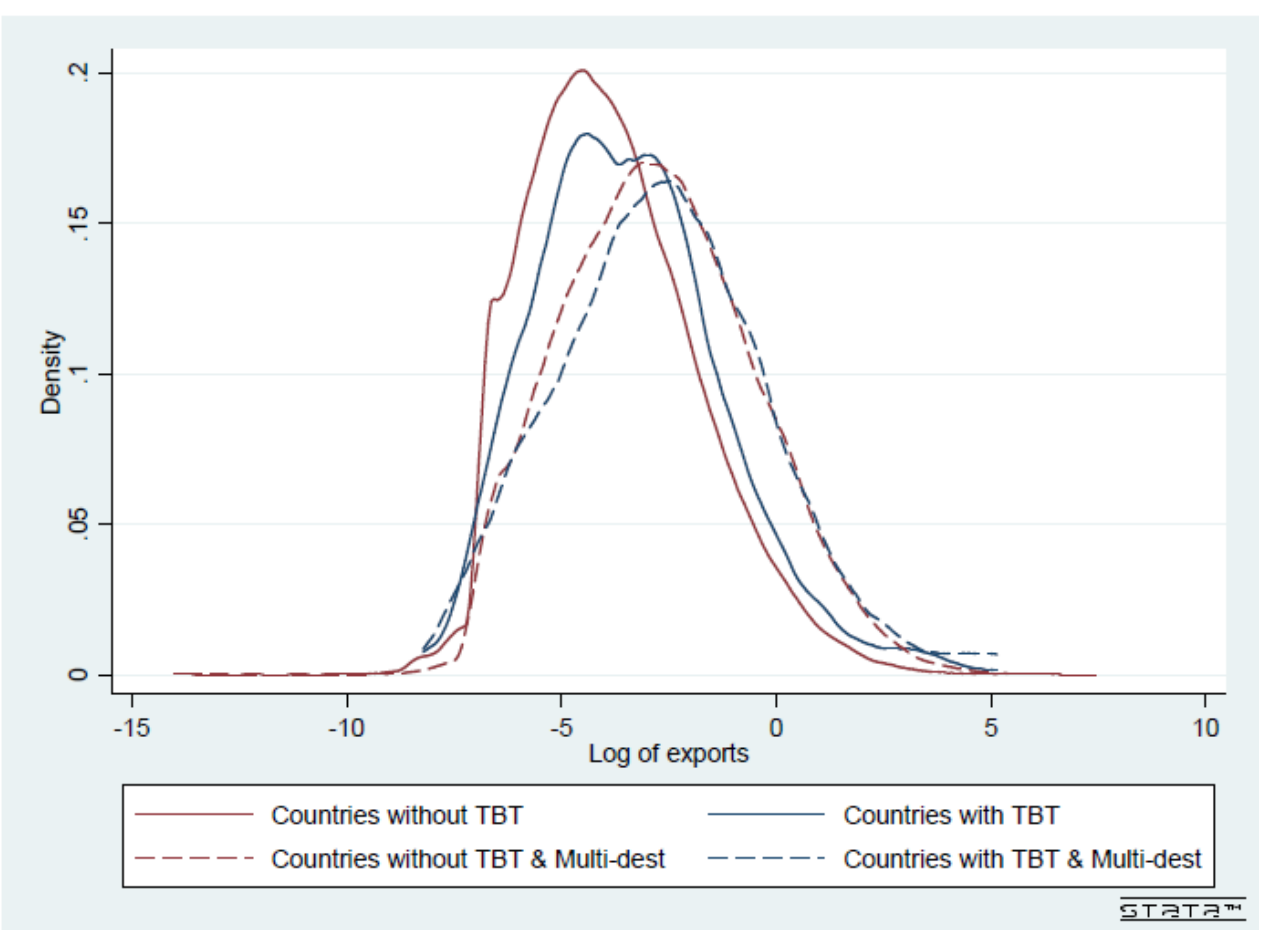

Source: Authors' calculation on French Custom Data. 
Table 5 - Number of exporters (i.e. firm-HS4 combinations) by bin and their export share over total French exports.

\begin{tabular}{lcc|cc}
\hline \hline Bins & \multicolumn{2}{c|}{$\begin{array}{c}\text { Number of exporting } \\
\text { firm-HS4 }\end{array}$} & \multicolumn{2}{|c}{$\begin{array}{c}\text { Export Share } \\
\text { (in \%) }\end{array}$} \\
\hline & 2000 & 2005 & 2000 & 2005 \\
\hline$l_{i, s, 1995}\left(k_{i, s, 1995}=0\right)$ & 65529 & 73956 & 23 & 32 \\
$l_{i, s, 1995}\left(0<k_{i, s, 1995} \leq 1\right)$ & 32092 & 19822 & 7 & 6 \\
$l_{i, s, 1995}\left(1<k_{i, s, 1995} \leq 6\right)$ & 19251 & 14513 & 16 & 12 \\
$l_{i, s, 1995}\left(6<k_{i, s, 1995} \leq 17\right)$ & 4403 & 3765 & 22 & 17 \\
$l_{i, s, 1995}\left(k_{i, s, 1995}>17\right)$ & 1417 & 1294 & 32 & 33 \\
\hline
\end{tabular}

Table 6 - Multi-destination premia in French firms, 1997-2007.

\begin{tabular}{lcc}
\hline \hline & \multicolumn{2}{c}{ Multi-destination premia } \\
\hline Exit Dummy & $-0.004^{* * *}$ & $-0.011^{* * *}$ \\
& $(0.001)$ & $(0.001)$ \\
Participation Dummy & $0.195^{* * *}$ & $0.199^{* * *}$ \\
& $(0.007)$ & $(0.006)$ \\
Log export & $1.199^{* * *}$ & $1.323^{* * *}$ \\
& $(0.056)$ & $(0.046)$ \\
Log export per product & $0.992^{* * *}$ & $1.076^{* * *}$ \\
& $(0.059)$ & $(0.042)$ \\
TUV & $-0.188^{* * *}$ & $-0.131^{* * *}$ \\
& $(0.032)$ & $(0.022)$ \\
\hline Destination-Product-Year FE & yes & yes \\
Firm FE & no & yes
\end{tabular}

Note: all results are from OLS regressions of the firms outcomes listed

on the left on a dummy variable being equal to one if the firm has

a number of TBT-free destinations in 1995 avobe the 90th percentile,

i.e. 17 destinations. 
Table 7 - Exit probability estimation

\begin{tabular}{|c|c|c|c|c|c|}
\hline \multirow[t]{2}{*}{ Dep. Var. } & \multicolumn{5}{|c|}{ Exit Dummy } \\
\hline & (1) & (2) & (3) & (4) & (5) \\
\hline \multirow[t]{2}{*}{ TBT } & $0.025 * * *$ & $0.016^{* *}$ & $0.015^{*}$ & $0.015^{*}$ & $0.016^{*}$ \\
\hline & $(0.008)$ & $(0.008)$ & $(0.008)$ & $(0.008)$ & $(0.008)$ \\
\hline \multirow[t]{2}{*}{$\operatorname{TBT}^{*} l_{i, s, 1995}\left(k_{i, s, 1995}>\bar{k}\right)$} & & & $0.011^{*}$ & $0.011^{*}$ & $0.014^{*}$ \\
\hline & & & $(0.006)$ & $(0.006)$ & $(0.008)$ \\
\hline \multirow[t]{2}{*}{$l_{i, s, 1995}\left(k_{i, s, 1995}>\bar{k}\right)$} & & & $-0.011 * * *$ & $-0.011^{* * *}$ & $-0.012 * * *$ \\
\hline & & & $(0.000)$ & $(0.000)$ & $(0.001)$ \\
\hline \multirow[t]{2}{*}{ TBT*Visibility 1995} & & & & -0.011 & -0.011 \\
\hline & & & & $(0.012)$ & $(0.012)$ \\
\hline \multirow[t]{2}{*}{ TBT*Firm size 1995} & & 0.002 & 0.002 & 0.003 & 0.003 \\
\hline & & $(0.001)$ & $(0.002)$ & $(0.002)$ & $(0.002)$ \\
\hline \multirow[t]{2}{*}{ TBT*Domestic Dummy 1995} & & $0.014^{* * *}$ & $0.015^{* * *}$ & $0.015^{* * *}$ & $0.015^{* * *}$ \\
\hline & & $(0.005)$ & $(0.005)$ & $(0.005)$ & $(0.005)$ \\
\hline \multirow[t]{2}{*}{$\log ($ tariff +1$)$} & $0.007^{* *}$ & $0.007^{* *}$ & $0.007^{* *}$ & $0.007^{* *}$ & $0.007^{* *}$ \\
\hline & $(0.003)$ & $(0.003)$ & $(0.003)$ & $(0.003)$ & $(0.003)$ \\
\hline Firm Fixed Effects & yes & yes & yes & yes & yes \\
\hline HS2-Destination-Year Fixed Effects & yes & yes & yes & yes & yes \\
\hline$k_{i, s, 1995}$ & \multicolumn{4}{|c|}{ \# TBT-free destinations in 1995} & \# destinations \\
\hline Observations & $5,879,232$ & $5,879,232$ & $5,879,232$ & $5,878,870$ & $5,878,870$ \\
\hline R-squared & 0.059 & 0.059 & 0.059 & 0.059 & 0.059 \\
\hline
\end{tabular}

Visibility and Domestic Dummy in 1995 are included but not reported when interacted with TBT.

Clustered standard errors by destination-HS4-year in parentheses.

$* * * p<0,01 ; * * p<0,05 ; * p<0,1$. 


\section{Table 8 - Extensive margin estimation}

\begin{tabular}{|c|c|c|c|c|c|}
\hline \multirow[t]{2}{*}{ Dep. Var. } & \multicolumn{5}{|c|}{ Participation Dummy } \\
\hline & (1) & (2) & (3) & (4) & (5) \\
\hline TBT & $\begin{array}{c}-0.046^{* * *} \\
(0.017)\end{array}$ & $\begin{array}{c}-0.065^{* * *} \\
(0.019)\end{array}$ & $\begin{array}{c}-0.064^{* * *} \\
(0.019)\end{array}$ & $\begin{array}{c}-0.065^{* * *} \\
(0.019)\end{array}$ & $\begin{array}{c}-0.065^{* * *} \\
(0.019)\end{array}$ \\
\hline $\mathrm{TBT}^{*} l_{i, s, 1995}\left(k_{i, s, 1995}>\bar{k}\right)$ & & & $\begin{array}{c}-0.046^{* * *} \\
(0.013)\end{array}$ & $\begin{array}{c}-0.044 * * * \\
(0.013)\end{array}$ & $\begin{array}{c}-0.056^{* * *} \\
(0.015)\end{array}$ \\
\hline$l_{i, s, 1995}\left(k_{i, s, 1995}>\bar{k}\right)$ & & & $\begin{array}{c}0.186^{* * *} \\
(0.001)\end{array}$ & $\begin{array}{c}0.186^{* * *} \\
(0.001)\end{array}$ & $\begin{array}{l}0.200^{* * *} \\
(0.001)\end{array}$ \\
\hline TBT*Visibility 1995 & & & & $\begin{array}{c}0.117^{* * *} \\
(0.026)\end{array}$ & $\begin{array}{c}0.115^{* * *} \\
(0.026)\end{array}$ \\
\hline TBT*Firm size 1995 & & $\begin{array}{c}-0.010^{* * *} \\
(0.003)\end{array}$ & $\begin{array}{c}-0.008^{* *} \\
(0.003)\end{array}$ & $\begin{array}{c}-0.021^{* * *} \\
(0.004)\end{array}$ & $\begin{array}{c}-0.020^{* * *} \\
(0.004)\end{array}$ \\
\hline TBT*Domestic Dummy 1995 & & $\begin{array}{c}0.081 * * * \\
(0.017)\end{array}$ & $\begin{array}{c}0.082 * * * \\
(0.017)\end{array}$ & $\begin{array}{c}0.083 * * * \\
(0.017)\end{array}$ & $\begin{array}{c}0.083 * * * \\
(0.017)\end{array}$ \\
\hline $\log ($ tariff +1$)$ & $\begin{array}{c}0.006 \\
(0.007)\end{array}$ & $\begin{array}{c}0.005 \\
(0.007)\end{array}$ & $\begin{array}{l}-0.000 \\
(0.007)\end{array}$ & $\begin{array}{l}-0.000 \\
(0.007)\end{array}$ & $\begin{array}{c}0.001 \\
(0.007)\end{array}$ \\
\hline Firm Fixed Effects & yes & yes & yes & yes & yes \\
\hline HS2-Destination-Year Fixed Effects & yes & yes & yes & yes & yes \\
\hline$k_{i, s, 1995}$ & \# T & BT-free des & tinations in & 1995 & \# destinations \\
\hline Observations & $5,879,232$ & $5,879,232$ & $5,879,232$ & $5,878,870$ & $5,878,870$ \\
\hline R-squared & 0.108 & 0.111 & 0.117 & 0.117 & 0.116 \\
\hline
\end{tabular}

Visibility and Domestic Dummy in 1995 are included but not reported when interacted with TBT.

Clustered standard errors by destination-HS4-year in parentheses.

*** $p<0,01 ; * * p<0,05 ; * p<0,1$. 
Table 9 - Intensive margin estimation

\begin{tabular}{|c|c|c|c|c|c|}
\hline \multirow[t]{2}{*}{ Dep. Var. } & \multicolumn{5}{|c|}{ Log of export value } \\
\hline & (1) & (2) & (3) & (4) & (5) \\
\hline \multirow[t]{2}{*}{ TBT } & 0.081 & 0.083 & 0.063 & 0.062 & 0.075 \\
\hline & $(0.076)$ & $(0.079)$ & $(0.076)$ & $(0.076)$ & $(0.076)$ \\
\hline \multirow[t]{2}{*}{$\operatorname{TBT}^{*} I_{i, s, 1995}\left(k_{i, s, 1995}>\bar{k}\right)$} & & & $0.145^{* *}$ & $0.146^{* *}$ & $0.142^{*}$ \\
\hline & & & $(0.070)$ & $(0.070)$ & $(0.079)$ \\
\hline \multirow[t]{2}{*}{$l_{i, s, 1995}\left(k_{i, s, 1995}>\bar{k}\right)$} & & & $1.244^{* * *}$ & $1.244^{* * *}$ & $1.352 * * *$ \\
\hline & & & $(0.006)$ & $(0.006)$ & $(0.007)$ \\
\hline \multirow[t]{2}{*}{ TBT*Visibility 1995} & & & & 0.062 & 0.043 \\
\hline & & & & $(0.168)$ & $(0.169)$ \\
\hline \multirow[t]{2}{*}{ TBT*Firm size 1995} & & 0.016 & -0.011 & -0.017 & -0.013 \\
\hline & & $(0.021)$ & $(0.019)$ & $(0.028)$ & $(0.029)$ \\
\hline \multirow[t]{2}{*}{ TBT*Domestic Dummy 1995} & & -0.057 & -0.015 & -0.015 & -0.027 \\
\hline & & $(0.046)$ & $(0.045)$ & $(0.045)$ & $(0.046)$ \\
\hline \multirow[t]{2}{*}{$\log ($ tariff +1$)$} & $-0.126 * * *$ & $-0.128 * * *$ & $-0.161^{* * *}$ & $-0.161 * * *$ & $-0.155^{* * *}$ \\
\hline & $(0.038)$ & $(0.037)$ & $(0.037)$ & $(0.037)$ & $(0.037)$ \\
\hline Firm Fixed Effects & yes & yes & yes & yes & yes \\
\hline HS2-Destination-Year Fixed Effects & yes & yes & yes & yes & yes \\
\hline$k_{i, s, 1995}$ & \multicolumn{4}{|c|}{ \# TBT-free destinations in 1995} & \# destinations \\
\hline Observations & $3,007,840$ & $3,007,840$ & $3,007,840$ & $3,007,660$ & $3,007,660$ \\
\hline R-squared & 0.324 & 0.336 & 0.354 & 0.354 & 0.353 \\
\hline
\end{tabular}

Visibility and Domestic Dummy in 1995 are included but not reported when interacted with TBT.

Clustered standard errors by destination-HS4-year in parentheses.

$* * * p<0,01 ; * * p<0,05 ; * p<0,1$. 
Table 10 - Export price estimation

\begin{tabular}{|c|c|c|c|c|c|}
\hline \multirow[t]{2}{*}{ Dep. Var. } & \multicolumn{5}{|c|}{ Log of Trade Unit Value } \\
\hline & (1) & $(2)$ & (3) & (4) & (5) \\
\hline \multirow[t]{2}{*}{ TBT } & $0.127^{* * *}$ & $0.097^{* *}$ & $0.101^{* *}$ & $0.101^{* *}$ & $0.099 * *$ \\
\hline & $(0.048)$ & $(0.047)$ & $(0.047)$ & $(0.047)$ & $(0.047)$ \\
\hline \multirow{2}{*}{$\operatorname{TBT}^{*} l_{i, s, 1995}\left(k_{i, s, 1995}>\bar{k}\right)$} & & & -0.057 & -0.056 & -0.062 \\
\hline & & & $(0.035)$ & $(0.035)$ & $(0.040)$ \\
\hline \multirow[t]{2}{*}{$l_{i, s, 1995}\left(k_{i, s, 1995}>\bar{k}\right)$} & & & $-0.099 * * *$ & $-0.099 * * *$ & $-0.122 * * *$ \\
\hline & & & $(0.003)$ & $(0.003)$ & $(0.004)$ \\
\hline \multirow[t]{2}{*}{ TBT*Visibility 1995} & & & & 0.022 & 0.022 \\
\hline & & & & $(0.069)$ & $(0.070)$ \\
\hline \multirow[t]{2}{*}{ TBT*Firm size 1995} & & -0.000 & 0.006 & 0.004 & 0.004 \\
\hline & & $(0.010)$ & $(0.011)$ & $(0.013)$ & $(0.013)$ \\
\hline \multirow[t]{2}{*}{ TBT*Domestic Dummy 1995} & & $0.073^{* * *}$ & $0.065 * * *$ & $0.065^{* * *}$ & $0.068 * * *$ \\
\hline & & $(0.027)$ & $(0.025)$ & $(0.025)$ & $(0.026)$ \\
\hline \multirow[t]{2}{*}{ Log(tariff+1) } & $-0.271^{* * *}$ & $-0.271^{* * *}$ & $-0.268 * * *$ & $-0.268 * * *$ & $-0.268 * * *$ \\
\hline & $(0.022)$ & $(0.022)$ & $(0.022)$ & $(0.022)$ & $(0.022)$ \\
\hline Firm Fixed Effects & yes & yes & yes & yes & yes \\
\hline HS2-Destination-Year Fixed Effects & yes & yes & yes & yes & yes \\
\hline$k_{i, s, 1995}$ & \multicolumn{4}{|c|}{ \# TBT-free destinations in 1995} & \# destinations \\
\hline Observations & $3,007,840$ & $3,007,840$ & $3,007,840$ & $3,007,660$ & $3,007,660$ \\
\hline R-squared & 0.771 & 0.771 & 0.771 & 0.771 & 0.771 \\
\hline
\end{tabular}

Visibility and Domestic Dummy in 1995 are included but not reported when interacted with TBT.

Clustered standard errors by destination-HS4-year in parentheses.

$* * * p<0,01 ; * * p<0,05 ; * p<0,1$. 


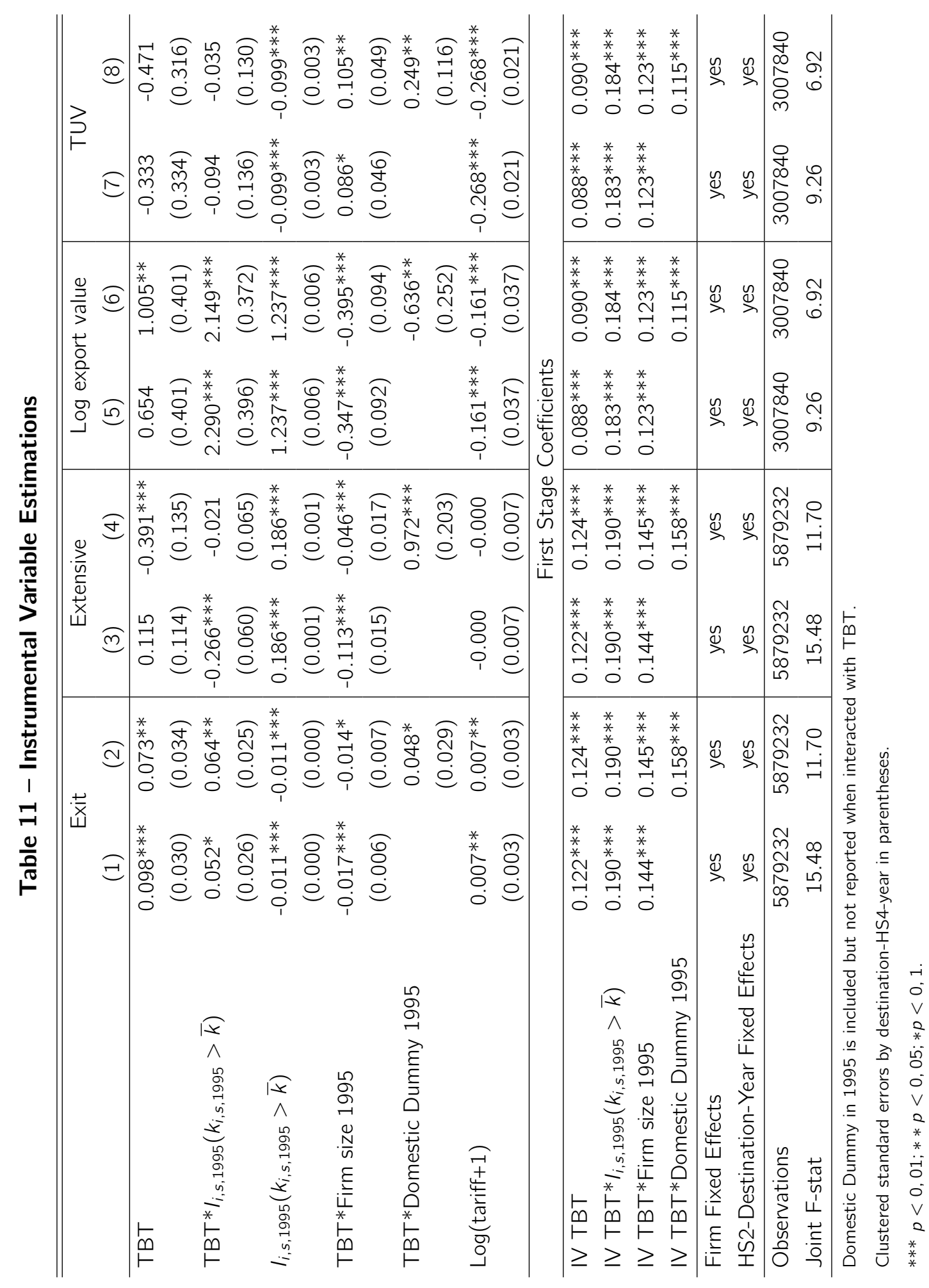




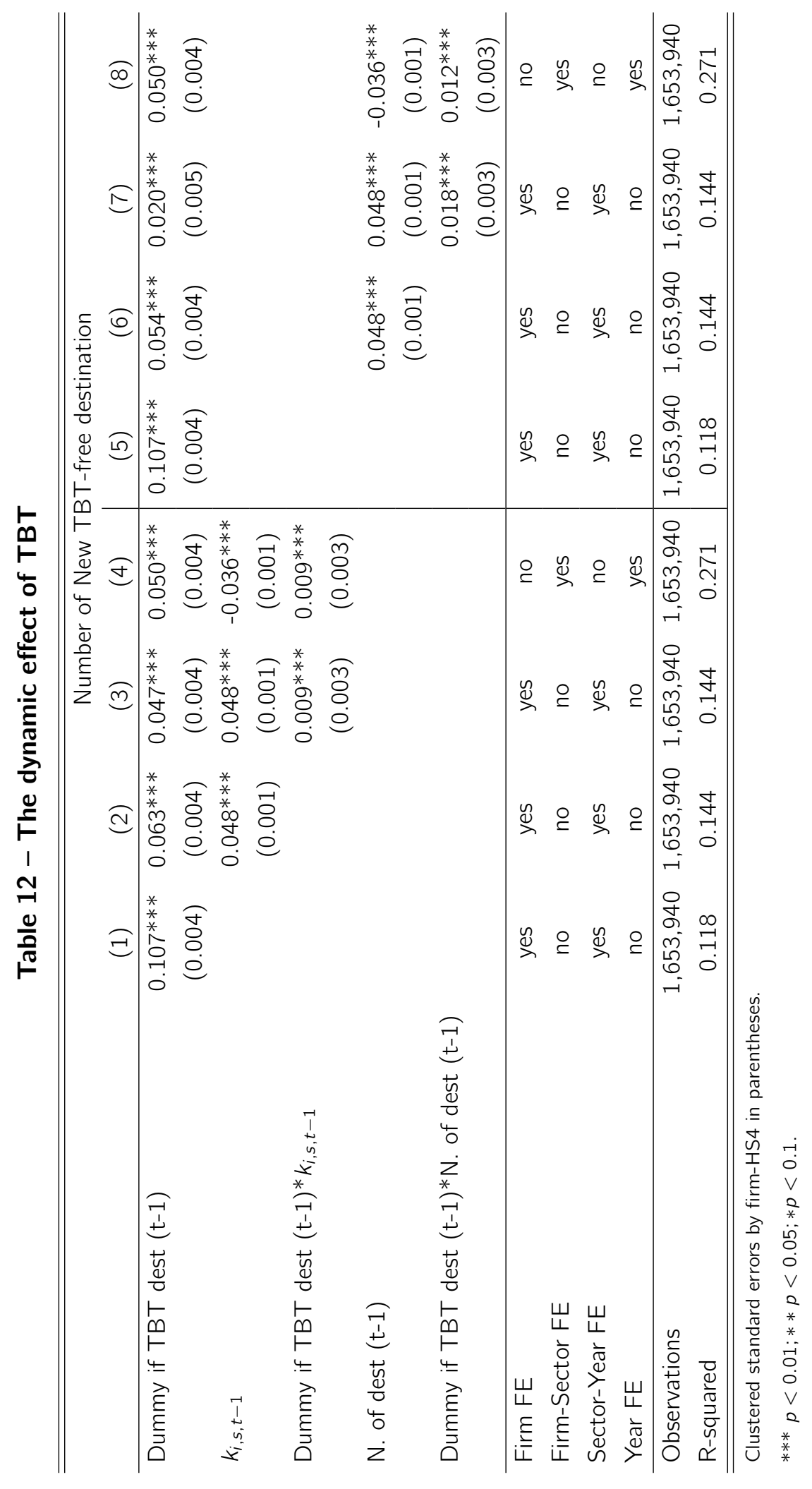




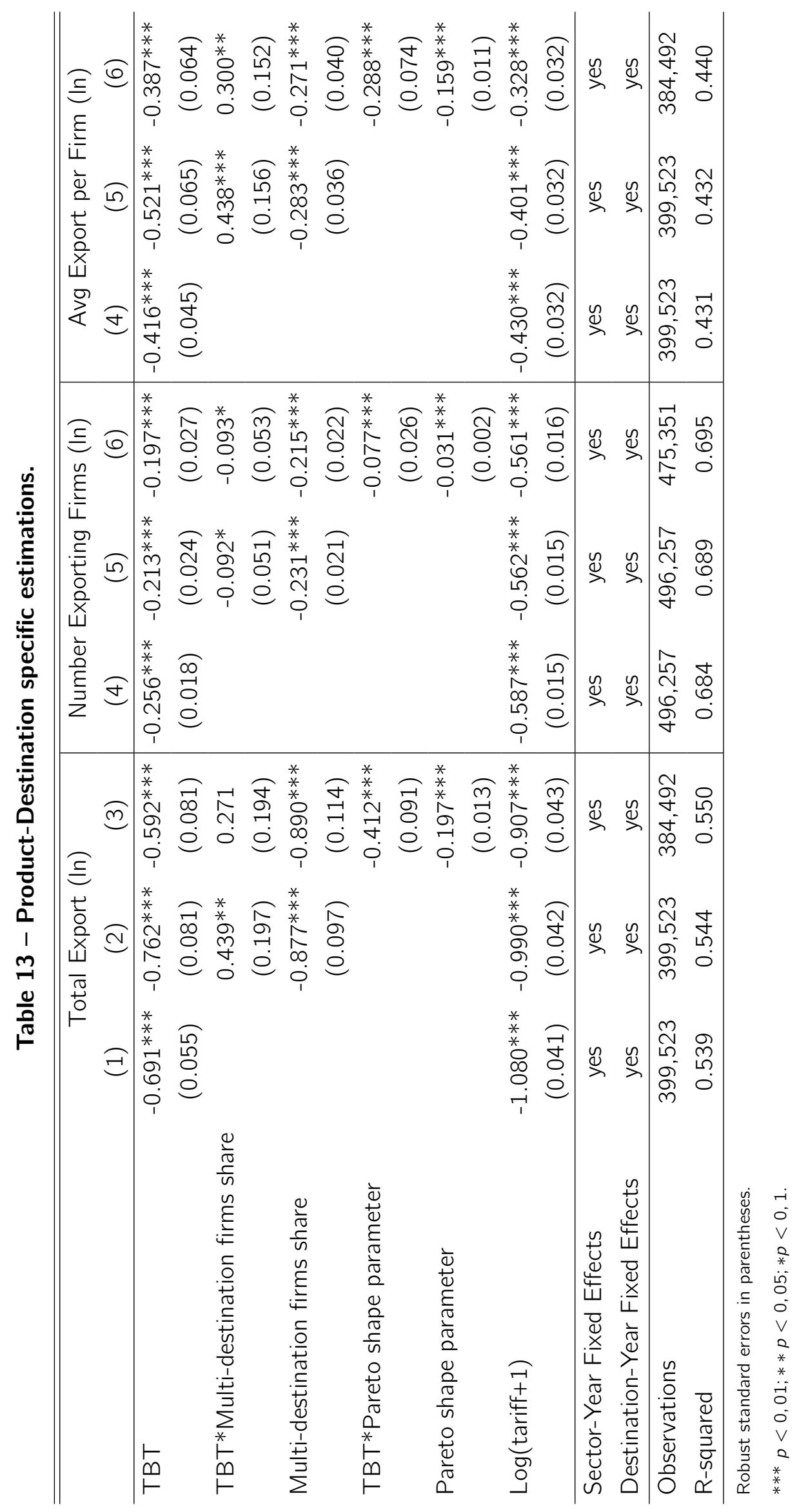


Table 14 - Aggregate export elasticities

\begin{tabular}{llcc}
\hline \hline$\hat{\beta}$ & $V_{i} / V$ & $\begin{array}{c}\text { Aggregate } \\
\text { Elasticity }\end{array}$ & $\begin{array}{c}\text { Aggregate } \\
\text { Elasticity } \\
(\% \text { of total) }\end{array}$ \\
\hline Intensive $-0.663^{* * *}$ & 0.307 & -0.203 & $32 \%$ \\
Extensive $-0.621^{* * *}$ & 0.692 & -0.429 & $68 \%$ \\
Total & & -0.632 & \\
\hline$-\widehat{\beta}$ is the estimated coefficient for TBT on a gravity type regression \\
having the (log of) total destination-product-year specific export \\
for respectively incumbent and new-entry exporters \\
$-V_{i} / V$ is the share of total aggregate exports by respectively \\
incumbent and new-entry exporters \\
- Aggregate Elasticity= $\widehat{\beta}^{*} V_{i} / V$
\end{tabular}




\section{Appendix}

\section{A1. QQ estimators for the Pareto shape parameter}

The Pareto distribution is characterized by a location parameter $\mu$ and a shape parameter $\gamma$. While the location parameter does not matter for trade cost elasticity, the shape parameter is crucial for the identification of aggregate trade elasticity to trade costs (see Chaney (2008); Head et al. (2014)). In particular, in Chaney (2008), the aggregate trade elasticity to variable trade cost is exactly equal to the Pareto shape parameter $\gamma$; while the trade elasticity to fixed trade cost is directly related to $\gamma$. The Pareto shape parameter is an inverse measure of the heterogeneity of exports across firms in a given sector and can be estimated using the QQ estimator as in (Head et al., 2014).

While Head et al. (2014) calculate the Pareto shape parameter using French firms exporting in Belgium in 2000, here we are interested in Pareto shape parameters for each sectordestination combination, so we apply the QQ estimator for each sector(HS2)-destination combination (we cannot use the HS4 aggregation since this gives an insufficient number of firms in a given sector-destination cell).

The QQ estimator basically consists of minimizing the sum of the squared errors between the theoretical and the empirical distribution quantiles. The empirical quantiles are the log of (sorted) export values for a given firm $i$ into a given sector-destination $H S 2, j$. The associated CDF function is equal to $\widehat{F_{i, H S 2, j}}=(i-0.3) /(n+0.4)$, where $i=1$ for the firm with minimum export value and $i=n$ for the top exporting firm. The theoretical quantiles are given by $Q_{i, H S 2, j}=\ln \left(x_{\min }\right)-(1 / \widetilde{\gamma}) \ln \left(1-\widehat{F_{i, H S 2, j}}\right)$ where $x_{\min }$ is the minimum exported value. The OLS coefficient of the term $-\ln \left(1-\widehat{F_{i, H S 2, j}}\right)$ gives an inverse measure of the empirical $\widetilde{\gamma}$, with the primitive distribution value of gamma easily reversed since $\gamma=(\sigma-1) \widetilde{\gamma}$ (we follow Head et al. (2014) and use $\sigma=4$ ).

Thus, by regressing the empirical on the theoretical distribution quantiles for each sector (HS2)-destination combination we obtain estimates of $1 / \widetilde{\gamma}$, and recover the primitive distribution shape parameters $\gamma$ for each sector(HS2)-destination. Table A1 presents a synthetic 
view of the $Q Q$ estimator results. We show the average (across sectors within destination) of $1 / \widetilde{\gamma}$ and $\gamma$ for a selection of four countries. Our estimates are similar to the estimation results reported in Head et al. (2014) - our average $\gamma$ across destinations is indeed very close to the value reported in Head et al. (2014).

Table A1 - QQ regressions. Averages of shape parameters across sectors by destinations.

\begin{tabular}{|c|c|c|c|c|c|}
\hline & $\begin{array}{c}\text { Mean across } \\
\text { countries }\end{array}$ & USA & Japan & China & Canada \\
\hline$\gamma$ & 2.132 & 1.574 & 1.658 & 2.046 & 1.920 \\
\hline$\widetilde{\gamma}$ & 1.1563 & 1.1986 & 1.883 & 1.619 & 1.657 \\
\hline$\gamma$ in Head et al.(2014) & \multicolumn{5}{|c|}{2.146} \\
\hline$\widetilde{\gamma}$ in Head et al.(2014) & \multicolumn{5}{|c|}{1.396} \\
\hline
\end{tabular}




\section{A2. Additional Tables.}

Table A2 - Robustness check using STCs raised by any country (not only EU raised STCs)

\begin{tabular}{|c|c|c|c|c|}
\hline & $\begin{array}{l}\text { Exit } \\
(1)\end{array}$ & $\begin{array}{c}\text { Extensive } \\
\text { (2) }\end{array}$ & $\begin{array}{c}\text { Exports }(\log ) \\
\text { (3) }\end{array}$ & $\begin{array}{l}\text { TUV } \\
(4)\end{array}$ \\
\hline \multirow[t]{2}{*}{$T B T_{t-1}$} & $0.012 *$ & $-0.076 * * *$ & 0.045 & $0.097 * *$ \\
\hline & $(0.007)$ & $(0.019)$ & $(0.071)$ & $(0.044)$ \\
\hline \multirow[t]{2}{*}{$\mathrm{TBT}^{*} I_{i, s, 1995}\left(k_{i, s, 1995}>\bar{k}\right)$} & 0.008 & $-0.040 * * *$ & $0.133^{* *}$ & $-0.058 *$ \\
\hline & $(0.006)$ & $(0.012)$ & $(0.067)$ & $(0.033)$ \\
\hline \multirow[t]{2}{*}{$l_{i, s, 1995}\left(k_{i, s, 1995}>\bar{k}\right)$} & $-0.011^{* * *}$ & $0.186^{* * *}$ & $1.244 * * *$ & $-0.099 * * *$ \\
\hline & $(0.000)$ & $(0.001)$ & $(0.006)$ & $(0.003)$ \\
\hline \multirow{2}{*}{$T B T_{t-1} *$ Visibility 1995} & -0.010 & $0.096 * * *$ & 0.079 & 0.000 \\
\hline & $(0.011)$ & $(0.025)$ & $(0.155)$ & $(0.064)$ \\
\hline \multirow[t]{2}{*}{ TBT $T_{t-1}$ *Firm size 1995} & 0.003 & $-0.016 * * *$ & -0.015 & 0.007 \\
\hline & $(0.002)$ & $(0.004)$ & $(0.027)$ & $(0.012)$ \\
\hline \multirow[t]{2}{*}{ TBT $T_{t-1}$ *Domestic Dummy 1995} & $0.014^{* * *}$ & $0.088 * * *$ & -0.016 & $0.063 * * *$ \\
\hline & $(0.004)$ & $(0.015)$ & $(0.043)$ & $(0.023)$ \\
\hline \multirow[t]{2}{*}{$\log ($ tariff +1$)$} & $0.007^{* *}$ & -0.000 & $-0.161^{* * *}$ & $-0.268 * * *$ \\
\hline & $(0.003)$ & $(0.007)$ & $(0.037)$ & $(0.022)$ \\
\hline Firm Fixed Effects & yes & yes & yes & yes \\
\hline HS2-Destination-Year Fixed Effects & yes & yes & yes & yes \\
\hline$k_{i, s, 1995}$ & \multicolumn{4}{|c|}{ \# TBT-free destinations in 1995} \\
\hline Observations & $5,878,870$ & $5,878,870$ & $3,007,660$ & $3,007,660$ \\
\hline R-squared & 0.059 & 0.117 & 0.354 & 0.771 \\
\hline
\end{tabular}

Bins non interacted are included but not reported. Visibility and Domestic Dummy in 1995 are included but not reported. Clustered standard errors by destination-HS4-year. $* * * p<0,01 ; * * p<0,05 ; * p<0,1$. 


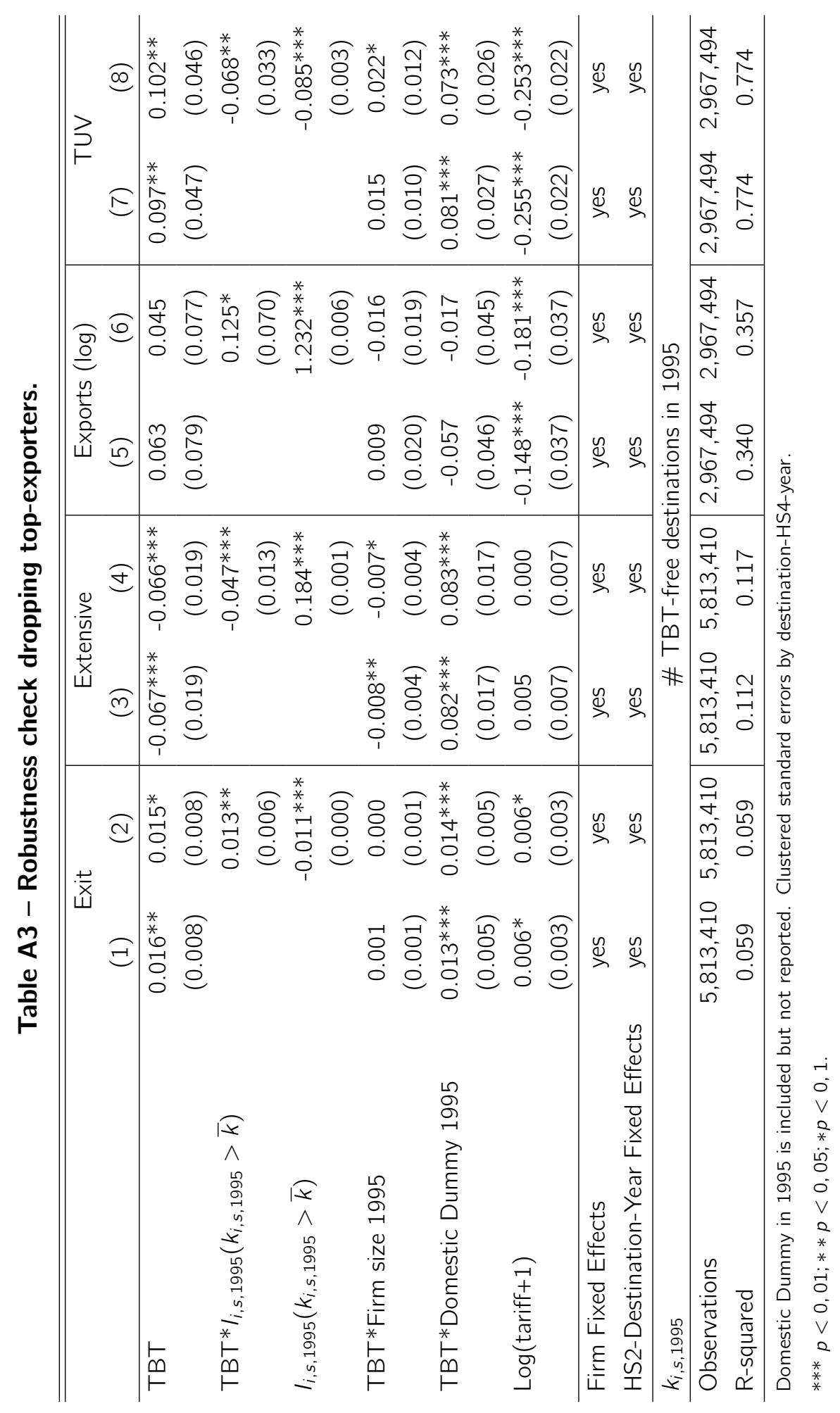




\section{On Line Appendix.}

Figure B1 - Number of TBT-free destinations in 1995

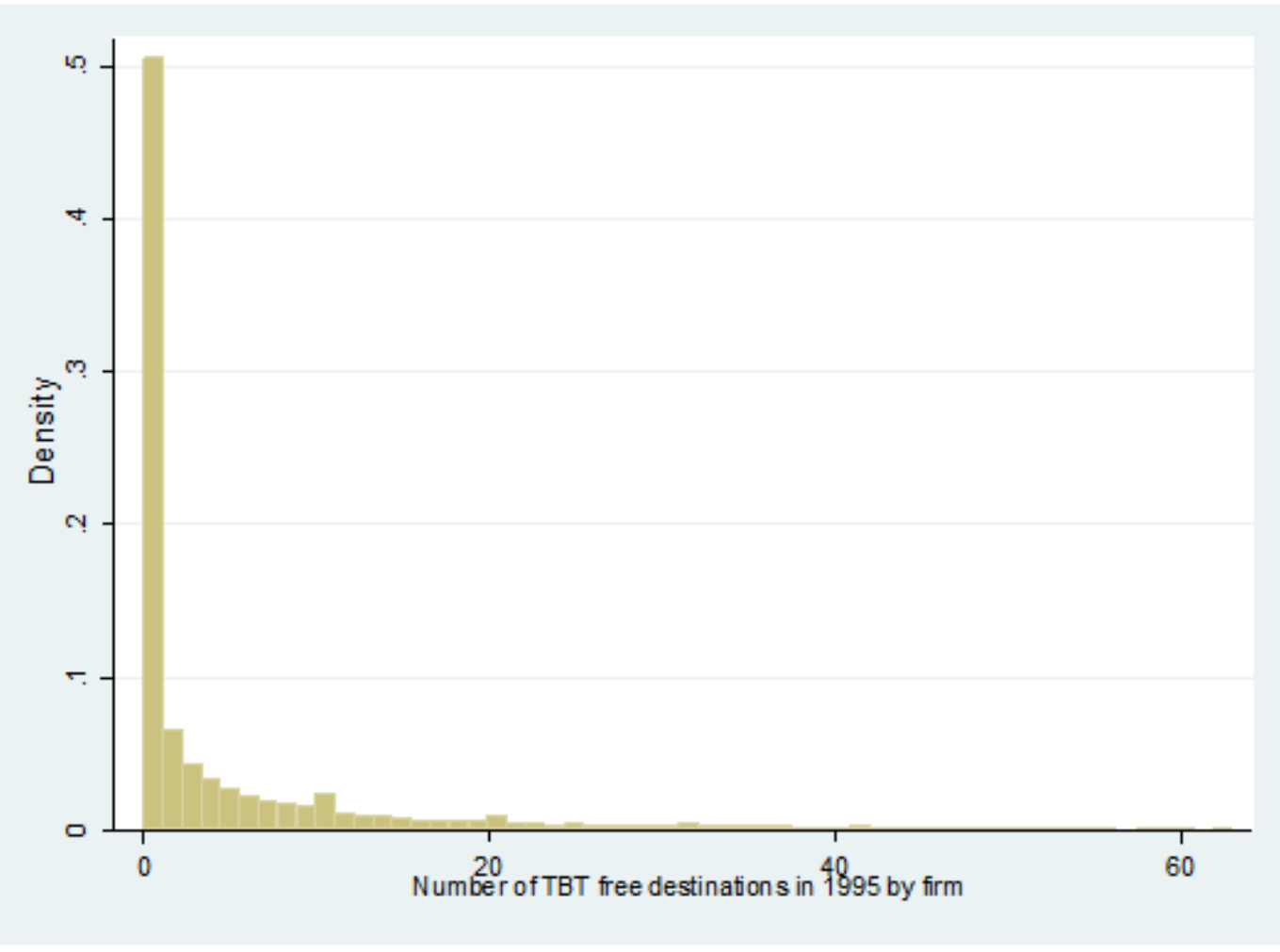

Source: Authors' calculation on French Custom Data. 
Figure B2 - Average duration of TBT concerns by imposing countries.

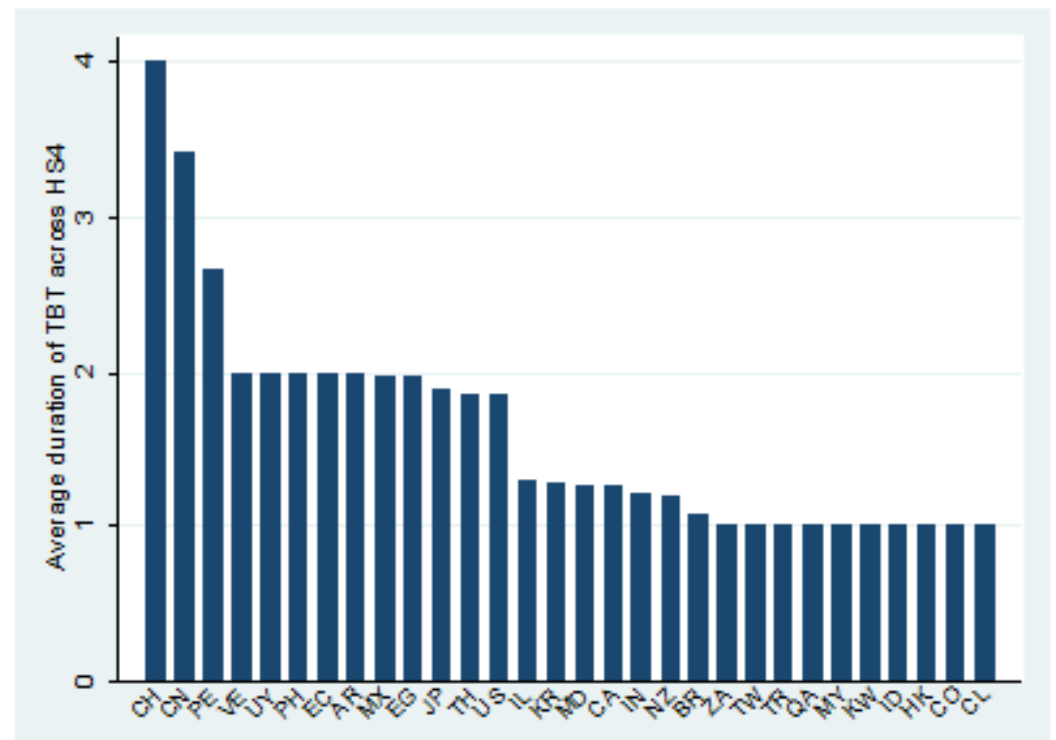

Source: Authors' calculation on WTO STC data.

Table B1 - Exit probability estimation

\begin{tabular}{|c|c|c|c|c|}
\hline \multirow[t]{2}{*}{ Dep. Var. } & \multicolumn{4}{|c|}{ Exit Dummy } \\
\hline & (1) & $(2)$ & (3) & (4) \\
\hline \multirow[t]{2}{*}{ TBT } & $0.016^{*}$ & $0.016^{*}$ & $0.016^{* *}$ & $0.016^{* *}$ \\
\hline & $(0.008)$ & $(0.008)$ & $(0.008)$ & $(0.008)$ \\
\hline \multirow{2}{*}{$\mathrm{TBT}^{*} I_{i, s, 1995}\left(k_{i, s, 1995}>\bar{k}\right)$} & $0.017^{* *}$ & $0.017^{* *}$ & $0.031^{*}$ & $0.031^{*}$ \\
\hline & $(0.008)$ & $(0.008)$ & $(0.018)$ & $(0.018)$ \\
\hline \multirow[t]{2}{*}{$l_{i, s, 1995}\left(k_{i, s, 1995}>\bar{k}\right)$} & $-0.014 * * *$ & $-0.014 * * *$ & $-0.016^{* * *}$ & $-0.016^{* * *}$ \\
\hline & $(0.001)$ & $(0.001)$ & $(0.001)$ & $(0.001)$ \\
\hline \multirow[t]{2}{*}{ TBT*Visibility 1995} & & -0.010 & & -0.011 \\
\hline & & $(0.012)$ & & $(0.012)$ \\
\hline \multirow[t]{2}{*}{ TBT*Firm size 1995} & 0.001 & 0.003 & 0.002 & 0.003 \\
\hline & $(0.002)$ & $(0.002)$ & $(0.001)$ & $(0.002)$ \\
\hline \multirow[t]{2}{*}{ TBT*Domestic Dummy 1995} & $0.015^{* * *}$ & $0.014 * * *$ & $0.014 * * *$ & $0.014 * * *$ \\
\hline & $(0.005)$ & $(0.005)$ & $(0.005)$ & $(0.005)$ \\
\hline \multirow[t]{2}{*}{$\log ($ tariff +1$)$} & $0.007^{* *}$ & $0.007^{* *}$ & $0.007^{* *}$ & $0.007^{* *}$ \\
\hline & $(0.003)$ & $(0.003)$ & $(0.003)$ & $(0.003)$ \\
\hline Firm Fixed Effects & yes & yes & yes & yes \\
\hline HS2-Destination-Year Fixed Effects & yes & yes & yes & yes \\
\hline$k_{i, s, 1995}$ & \multicolumn{4}{|c|}{ \# TBT-free destinations in 1995} \\
\hline Threshold $\bar{k}$ & \multicolumn{2}{|c|}{ Top 5 percentile of $k_{i, s, 1995}$} & \multicolumn{2}{|c|}{ Top 1 percentile of $k_{i, s, 1995}$} \\
\hline Observations & $5,879,232$ & $5,878,870$ & $5,879,232$ & $5,878,870$ \\
\hline R-squared & 0.059 & 0.059 & 0.059 & 0.059 \\
\hline
\end{tabular}

Visibility and Domestic Dummy in 1995 are included but not reported when interacted with TBT.

Clustered standard errors by destination-HS4-year in parentheses.

$* * * p<0,01 ; * * p<0,05 ; * p<0,1$. 
Table B2 - Extensive margin estimation

\begin{tabular}{|c|c|c|c|c|}
\hline \multirow[t]{2}{*}{ Dep. Var. } & \multicolumn{4}{|c|}{ Participation Dummy } \\
\hline & (1) & (2) & (3) & (4) \\
\hline TBT & $\begin{array}{c}-0.064 * * * \\
(0.019)\end{array}$ & $\begin{array}{c}-0.065^{* * *} \\
(0.019)\end{array}$ & $\begin{array}{c}-0.066 * * * \\
(0.019)\end{array}$ & $\begin{array}{c}-0.067^{* * *} \\
(0.019)\end{array}$ \\
\hline $\mathrm{TBT}^{*} l_{i, s, 1995}\left(k_{i, s, 1995}>\bar{k}\right)$ & $\begin{array}{c}-0.065^{* * *} \\
(0.016)\end{array}$ & $\begin{array}{c}-0.060 * * * \\
(0.016)\end{array}$ & $\begin{array}{c}-0.068^{* *} \\
(0.027)\end{array}$ & $\begin{array}{c}-0.065^{* *} \\
(0.027)\end{array}$ \\
\hline$I_{i, s, 1995}\left(k_{i, s, 1995}>\bar{k}\right)$ & $\begin{array}{c}0.208^{* * *} \\
(0.001)\end{array}$ & $\begin{array}{c}0.208^{* * *} \\
(0.001)\end{array}$ & $\begin{array}{c}0.240^{* * *} \\
(0.002)\end{array}$ & $\begin{array}{c}0.240^{* * *} \\
(0.002)\end{array}$ \\
\hline TBT*Visibility 1995 & & $\begin{array}{c}0.116^{* * *} \\
(0.026)\end{array}$ & & $\begin{array}{c}0.113^{* * *} \\
(0.026)\end{array}$ \\
\hline TBT*Firm size 1995 & $\begin{array}{c}-0.008^{* *} \\
(0.003)\end{array}$ & $\begin{array}{c}-0.020^{* * *} \\
(0.004)\end{array}$ & $\begin{array}{c}-0.010^{* * *} \\
(0.003)\end{array}$ & $\begin{array}{c}-0.022^{* * *} \\
(0.004)\end{array}$ \\
\hline TBT*Domestic Dummy 1995 & $\begin{array}{c}0.082^{* * *} \\
(0.017)\end{array}$ & $\begin{array}{c}0.083 * * * \\
(0.017)\end{array}$ & $\begin{array}{c}0.082^{* * *} \\
(0.017)\end{array}$ & $\begin{array}{c}0.083 * * * \\
(0.017)\end{array}$ \\
\hline Log(tariff+1) & $\begin{array}{c}0.002 \\
(0.007)\end{array}$ & $\begin{array}{c}0.002 \\
(0.007)\end{array}$ & $\begin{array}{c}0.003 \\
(0.007)\end{array}$ & $\begin{array}{c}0.003 \\
(0.007)\end{array}$ \\
\hline Firm Fixed Effects & yes & yes & yes & yes \\
\hline HS2-Destination-Year Fixed Effects & yes & yes & yes & yes \\
\hline$k_{i, s, 1995}$ & & TBT-free des & tinations in & \\
\hline Threshold $\bar{k}$ & Top 5 perc & tile of $k_{i, s, 1995}$ & Top 1 perc & tile of $k_{i, s, 1995}$ \\
\hline Observations & $5,879,232$ & $5,878,870$ & $5,879,232$ & $5,878,870$ \\
\hline R-squared & 0.116 & 0.116 & 0.113 & 0.113 \\
\hline
\end{tabular}

Visibility and Domestic Dummy in 1995 are included but not reported when interacted with TBT.

Clustered standard errors by destination-HS4-year in parentheses.

$* * * \quad p<0,01 ; * * p<0,05 ; * p<0,1$. 
Table B3 - Intensive margin estimation

\begin{tabular}{|c|c|c|c|c|}
\hline \multirow[t]{2}{*}{ Dep. Var. } & \multicolumn{4}{|c|}{ Log of export value } \\
\hline & (1) & $(2)$ & (3) & (4) \\
\hline \multirow[t]{2}{*}{ TBT } & 0.082 & 0.082 & 0.074 & 0.074 \\
\hline & $(0.076)$ & $(0.076)$ & $(0.078)$ & $(0.078)$ \\
\hline \multirow[t]{2}{*}{$\mathrm{TBT}^{*} l_{i, s, 1995}\left(k_{i, s, 1995}>\bar{k}\right)$} & 0.120 & 0.122 & 0.206 & 0.206 \\
\hline & $(0.091)$ & $(0.090)$ & $(0.167)$ & $(0.167)$ \\
\hline \multirow[t]{2}{*}{$l_{i, s, 1995}\left(k_{i, s, 1995}>\bar{k}\right)$} & $1.436 * * *$ & $1.436 * * *$ & $1.975^{* * *}$ & $1.975^{* * *}$ \\
\hline & $(0.007)$ & $(0.007)$ & $(0.013)$ & $(0.013)$ \\
\hline \multirow[t]{2}{*}{ TBT*Visibility 1995} & & 0.056 & & 0.018 \\
\hline & & $(0.169)$ & & $(0.170)$ \\
\hline \multirow[t]{2}{*}{ TBT*Firm size 1995} & -0.007 & -0.013 & -0.008 & -0.009 \\
\hline & $(0.020)$ & $(0.030)$ & $(0.020)$ & $(0.031)$ \\
\hline \multirow[t]{2}{*}{ TBT*Domestic Dummy 1995} & -0.031 & -0.030 & -0.047 & -0.047 \\
\hline & $(0.045)$ & $(0.046)$ & $(0.046)$ & $(0.046)$ \\
\hline \multirow[t]{2}{*}{$\log ($ tariff +1$)$} & $-0.150 * * *$ & $-0.150 * * *$ & $-0.146^{* * *}$ & $-0.146^{* * *}$ \\
\hline & $(0.037)$ & $(0.037)$ & $(0.036)$ & $(0.036)$ \\
\hline Firm Fixed Effects & yes & yes & yes & yes \\
\hline HS2-Destination-Year Fixed Effects & yes & yes & yes & yes \\
\hline$k_{i, s, 1995}$ & \multicolumn{4}{|c|}{ \# TBT-free destinations in 1995} \\
\hline Threshold $\bar{k}$ & \multicolumn{2}{|c|}{ Top 5 percentile of $k_{i, s, 1995}$} & \multicolumn{2}{|c|}{ Top 1 percentile of $k_{i, s, 1995}$} \\
\hline Observations & $3,007,840$ & $3,007,660$ & $3,007,840$ & $3,007,660$ \\
\hline R-squared & 0.352 & 0.352 & 0.346 & 0.346 \\
\hline
\end{tabular}

Visibility and Domestic Dummy in 1995 are included but not reported when interacted with TBT.

Clustered standard errors by destination-HS4-year in parentheses.

*** $p<0,01 ; * * p<0,05 ; * p<0,1$. 
Table B4 - Export price estimation

\begin{tabular}{|c|c|c|c|c|}
\hline \multirow[t]{2}{*}{ Dep. Var. } & \multicolumn{4}{|c|}{ Log of Trade Unit Value } \\
\hline & $(1)$ & $(2)$ & (3) & (4) \\
\hline \multirow[t]{2}{*}{ TBT } & $0.097^{* *}$ & $0.097^{* *}$ & $0.097^{* *}$ & $0.097^{* *}$ \\
\hline & $(0.047)$ & $(0.047)$ & $(0.047)$ & $(0.047)$ \\
\hline \multirow{2}{*}{$\mathrm{TBT}^{*} I_{i, s, 1995}\left(k_{i, s, 1995}>\bar{k}\right)$} & $-0.086^{*}$ & $-0.085^{*}$ & -0.066 & -0.066 \\
\hline & $(0.046)$ & $(0.046)$ & $(0.088)$ & $(0.088)$ \\
\hline \multirow[t]{2}{*}{$l_{i, s, 1995}\left(k_{i, s, 1995}>\bar{k}\right)$} & $-0.118^{* * *}$ & $-0.118^{* * *}$ & $-0.238 * * *$ & $-0.238^{* * *}$ \\
\hline & $(0.004)$ & $(0.004)$ & $(0.007)$ & $(0.007)$ \\
\hline \multirow[t]{2}{*}{ TBT*Visibility 1995} & & 0.018 & & 0.026 \\
\hline & & $(0.070)$ & & $(0.069)$ \\
\hline \multirow[t]{2}{*}{ TBT*Firm size 1995} & 0.007 & 0.005 & 0.004 & 0.001 \\
\hline & $(0.011)$ & $(0.013)$ & $(0.011)$ & $(0.012)$ \\
\hline \multirow[t]{2}{*}{ TBT*Domestic Dummy 1995} & $0.068^{* * *}$ & $0.068 * * *$ & $0.072^{* * *}$ & $0.072 * * *$ \\
\hline & $(0.026)$ & $(0.026)$ & $(0.026)$ & $(0.026)$ \\
\hline \multirow[t]{2}{*}{ Log(tariff+1) } & $-0.269 * * *$ & $-0.269 * * *$ & $-0.269 * * *$ & $-0.269 * * *$ \\
\hline & $(0.022)$ & $(0.022)$ & $(0.022)$ & $(0.022)$ \\
\hline Firm Fixed Effects & yes & yes & yes & yes \\
\hline HS2-Destination-Year Fixed Effects & yes & yes & yes & yes \\
\hline$k_{i, s, 1995}$ & \multicolumn{4}{|c|}{ \# TBT-free destinations in 1995} \\
\hline Threshold $\bar{k}$ & \multicolumn{2}{|c|}{ Top 5 percentile of $k_{i, s, 1995}$} & \multicolumn{2}{|c|}{ Top 1 percentile of $k_{i, s, 1995}$} \\
\hline Observations & $3,007,840$ & $3,007,660$ & $3,007,840$ & $3,007,660$ \\
\hline R-squared & 0.771 & 0.771 & 0.771 & 0.771 \\
\hline
\end{tabular}

Visibility and Domestic Dummy in 1995 are included but not reported when interacted with TBT.

Clustered standard errors by destination-HS4-year in parentheses.

$* * * \quad p<0,01 ; * * p<0,05 ; * p<0,1$. 


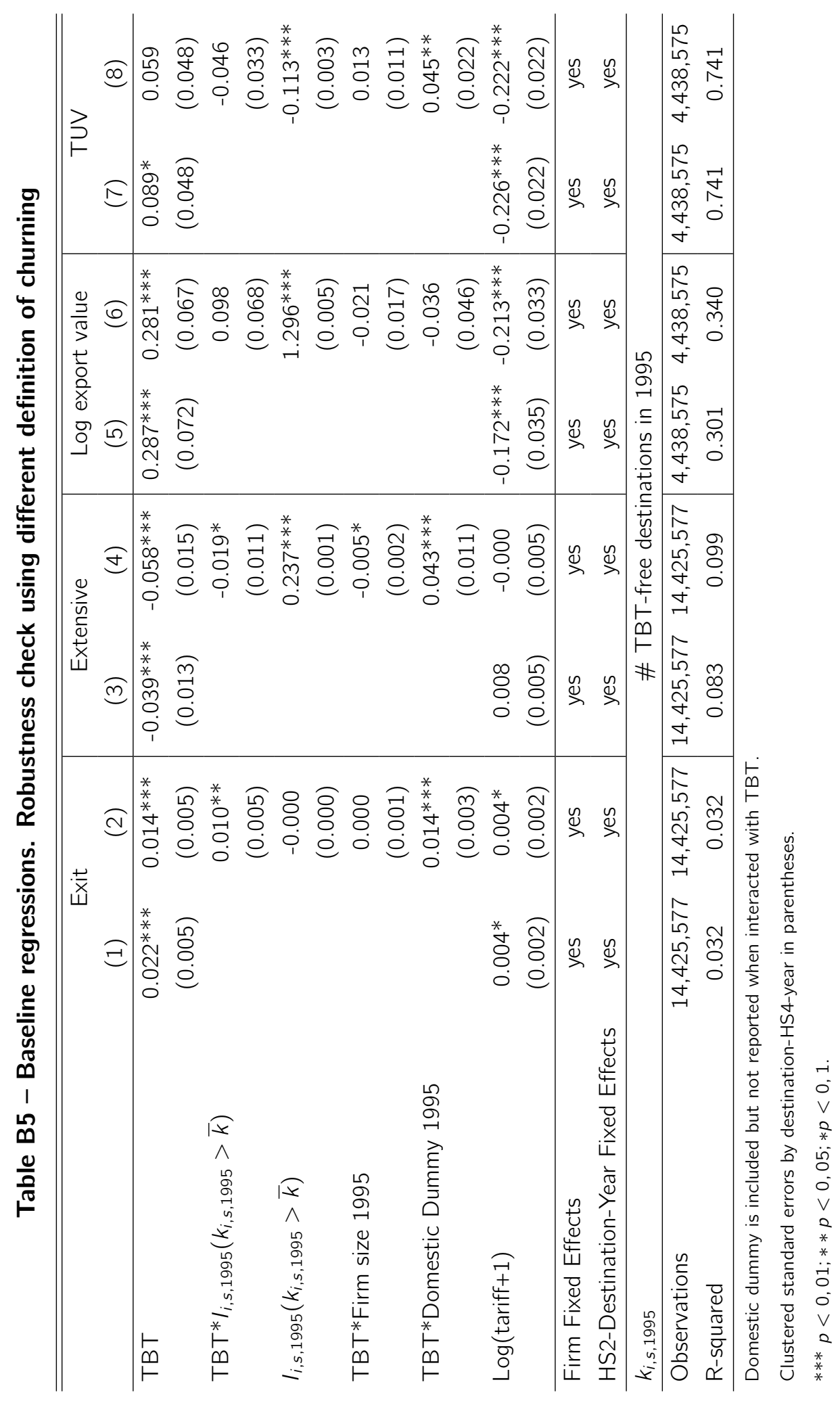


Table B6 - Robustness check including also HS4-destination fixed effects.

\begin{tabular}{|c|c|c|c|c|}
\hline Dep. Var. & Exit & Participation & Log(export) & $\log (T U V)$ \\
\hline & (1) & (2) & (3) & (4) \\
\hline \multirow[t]{2}{*}{ TBT } & $0.015^{* *}$ & $-0.071 * * *$ & -0.054 & $-0.048 *$ \\
\hline & $(0.007)$ & $(0.018)$ & $(0.053)$ & $(0.027)$ \\
\hline \multirow[t]{2}{*}{$\mathrm{TBT}^{*} I_{i, s, 1995}\left(k_{i, s, 1995}>\bar{k}\right)$} & $0.010 *$ & $-0.037 * * *$ & $0.144^{* *}$ & 0.002 \\
\hline & $(0.006)$ & $(0.012)$ & $(0.066)$ & $(0.031)$ \\
\hline \multirow[t]{2}{*}{$l_{i, s, 1995}\left(k_{i, s, 1995}>\bar{k}\right)$} & $-0.011 * * *$ & $0.186 * * *$ & $1.215^{* * *}$ & $-0.117 * * *$ \\
\hline & $(0.000)$ & $(0.001)$ & $(0.007)$ & $(0.004)$ \\
\hline \multirow[t]{2}{*}{ TBT*Visibility 1995} & -0.011 & $0.126 * * *$ & 0.138 & 0.077 \\
\hline & $(0.012)$ & $(0.026)$ & $(0.153)$ & $(0.068)$ \\
\hline \multirow[t]{2}{*}{ TBT*Firm size 1995} & 0.002 & $-0.022 * * *$ & -0.038 & $-0.020^{*}$ \\
\hline & $(0.002)$ & $(0.004)$ & $(0.027)$ & $(0.012)$ \\
\hline \multirow[t]{2}{*}{ TBT*Domestic Dummy 1995} & $0.015^{* * *}$ & $0.083^{* * *}$ & -0.005 & 0.014 \\
\hline & $(0.005)$ & $(0.018)$ & $(0.039)$ & $(0.019)$ \\
\hline \multirow[t]{2}{*}{$\log ($ tariff +1$)$} & -0.003 & $0.024 *$ & $0.079 * *$ & $-0.046 * *$ \\
\hline & $(0.006)$ & $(0.013)$ & $(0.034)$ & $(0.019)$ \\
\hline Firm Fixed Effects & yes & yes & yes & yes \\
\hline HS2-Destination-Year Fixed Effects & yes & yes & yes & yes \\
\hline HS4-Destination & yes & yes & yes & yes \\
\hline$k_{i, s, 1995}$ & \multicolumn{4}{|c|}{ \# TBT-free destinations in 1995} \\
\hline Observations & $5,878,870$ & $5,878,870$ & $3,007,660$ & $3,007,660$ \\
\hline R-squared & 0.063 & 0.129 & 0.415 & 0.807 \\
\hline
\end{tabular}

Visibility and Domestic Dummy in 1995 are included but not reported when interacted with TBT.

Clustered standard errors by destination-HS4-year in parentheses.

*** $p<0,01 ; * * p<0,05 ; * p<0,1$. 
Table B7 - Robustness check using binned model.

\begin{tabular}{|c|c|c|c|c|}
\hline Dep. Var. & Exit & Participation & $\log ($ export $)$ & $\log (T U V)$ \\
\hline & $(1)$ & $(2)$ & $(3)$ & $(4)$ \\
\hline $\mathrm{TBT}^{*} I_{i, s, 1995}\left(k_{i, s, 1995}>17\right)$ & $\begin{array}{c}0.025 * * * \\
(0.010)\end{array}$ & $\begin{array}{c}-0.108 * * * \\
(0.022)\end{array}$ & $\begin{array}{l}0.196 * \\
(0.109)\end{array}$ & $\begin{array}{c}0.044 \\
(0.056)\end{array}$ \\
\hline $\mathrm{TBT}^{*} l_{i, s, 1995}\left(6<k_{i, s, 1995} \leq 17\right)$ & $\begin{array}{c}0.010 \\
(0.008)\end{array}$ & $\begin{array}{c}-0.059 * * * \\
(0.019)\end{array}$ & $\begin{array}{c}0.023 \\
(0.097)\end{array}$ & $\begin{array}{l}0.096^{*} \\
(0.049)\end{array}$ \\
\hline $\mathrm{TBT}^{*} I_{i, s, 1995}\left(1<k_{i, s, 1995} \leq 6\right)$ & $\begin{array}{c}0.013 \\
(0.008)\end{array}$ & $\begin{array}{c}-0.073 * * * \\
(0.019)\end{array}$ & $\begin{array}{c}0.052 \\
(0.081)\end{array}$ & $\begin{array}{l}0.105 * * \\
(0.050)\end{array}$ \\
\hline $\mathrm{TBT}^{*} I_{i, s, 1995}\left(0<k_{i, s, 1995} \leq 1\right)$ & $\begin{array}{l}0.022 * * \\
(0.010)\end{array}$ & $\begin{array}{c}-0.067^{* * *} \\
(0.022)\end{array}$ & $\begin{array}{c}0.051 \\
(0.108)\end{array}$ & $\begin{array}{c}0.106 * * \\
(0.052)\end{array}$ \\
\hline $\mathrm{TBT}^{*} I_{i, s, 1995}\left(k_{i, s, 1995}=0\right)$ & $\begin{array}{c}0.054 \\
(0.065)\end{array}$ & $\begin{array}{l}-0.130 \\
(0.112)\end{array}$ & $\begin{array}{c}0.345 \\
(0.733)\end{array}$ & $\begin{array}{c}0.353 \\
(0.350)\end{array}$ \\
\hline TBT*Firm size 1995 & $\begin{array}{c}0.003 \\
(0.002)\end{array}$ & $\begin{array}{c}-0.021 * * * \\
(0.004)\end{array}$ & $\begin{array}{l}-0.016 \\
(0.026)\end{array}$ & $\begin{array}{c}0.004 \\
(0.013)\end{array}$ \\
\hline TBT*Domestic Dummy 1995 & $\begin{array}{l}-0.024 \\
(0.066)\end{array}$ & $\begin{array}{c}0.152 \\
(0.113)\end{array}$ & $\begin{array}{l}-0.285 \\
(0.733)\end{array}$ & $\begin{array}{l}-0.188 \\
(0.350)\end{array}$ \\
\hline$l_{i, s, 1995}\left(k_{i, s, 1995}>22\right)$ & $\begin{array}{l}-0.010 \\
(0.007)\end{array}$ & $\begin{array}{c}0.277^{* * *} \\
(0.021)\end{array}$ & $\begin{array}{c}2.300 * * * \\
(0.084)\end{array}$ & $\begin{array}{c}-0.087^{*} \\
(0.051)\end{array}$ \\
\hline TBT*Visibility 1995 & $\begin{array}{l}-0.011 \\
(0.012)\end{array}$ & $\begin{array}{c}0.121^{* * *} \\
(0.026)\end{array}$ & $\begin{array}{c}0.083 \\
(0.164)\end{array}$ & $\begin{array}{c}0.019 \\
(0.070)\end{array}$ \\
\hline $\log ($ tariff +1$)$ & $\begin{array}{c}0.007 * * \\
(0.003)\end{array}$ & $\begin{array}{l}-0.003 \\
(0.007)\end{array}$ & $\begin{array}{c}-0.171^{* * *} \\
(0.037)\end{array}$ & $\begin{array}{c}-0.267^{* * * *} \\
(0.022)\end{array}$ \\
\hline Firm Fixed Effects & yes & yes & yes & yes \\
\hline HS2-Destination-Year Fixed Effects & yes & yes & yes & yes \\
\hline$k_{i, s, 1995}$ & \multicolumn{4}{|c|}{ \# TBT-free destinations in 1995} \\
\hline Observations & $5,878,870$ & $5,878,870$ & $3,007,660$ & $3,007,660$ \\
\hline R-squared & 0.059 & 0.120 & 0.360 & 0.771 \\
\hline
\end{tabular}

Bins non interacted are included but not reported. Visibility and Domestic Dummy in 1995 are included but not reported when interacted with TBT. Clustered standard errors by destination-HS4-year in parentheses. ${ }^{* * *} p<0,01 ; * * p<0,05 ; * p<0,1$. 


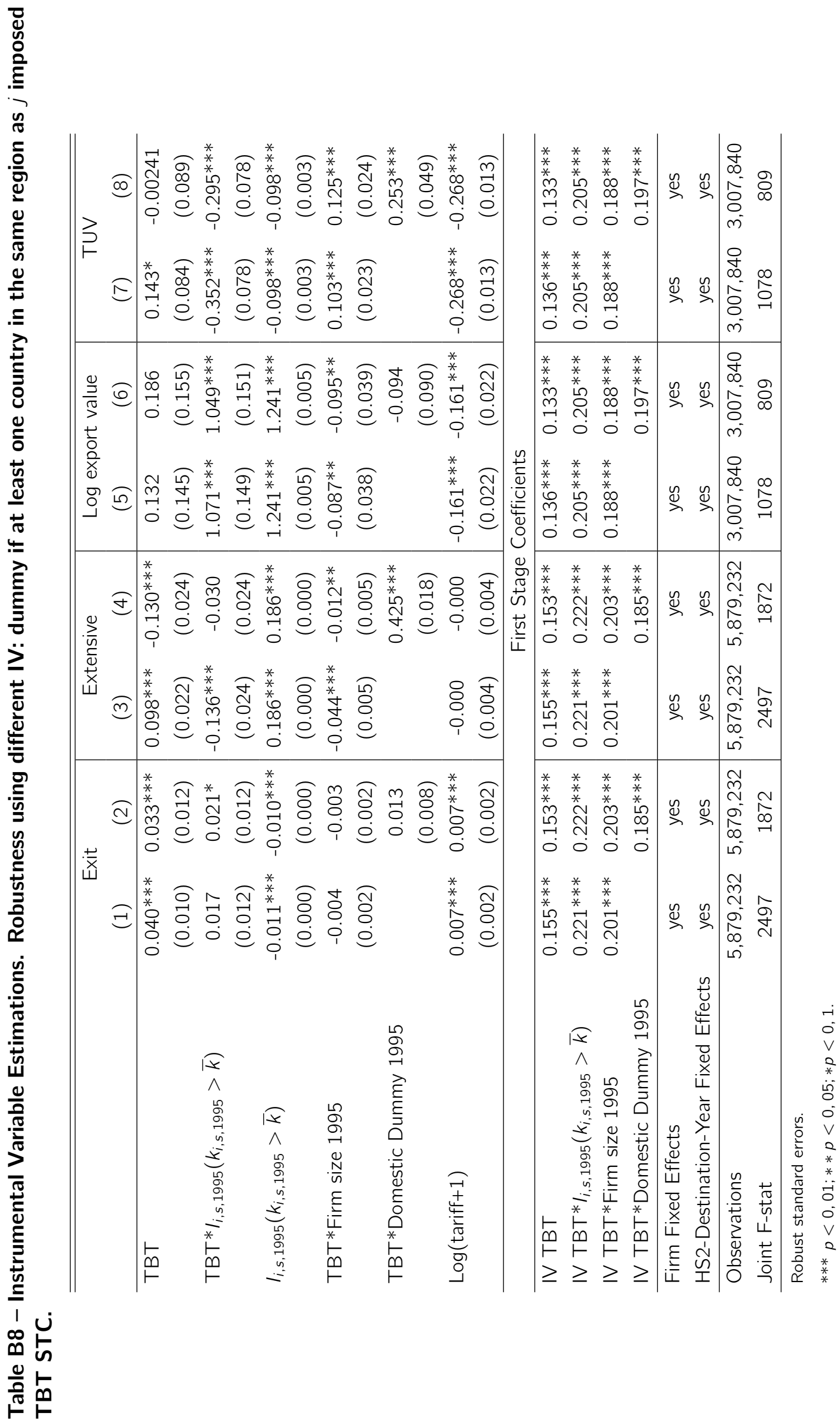

